\title{
Resilience in social housing developments through post-occupancy evaluation and co- production
}

\author{
Resiliência em conjuntos de habitação social: avaliação \\ pós-ocupação e co-produção
}

\section{Fernando Garrefa \\ Simone Barbosa Villa \\ Karen Carrer Ruman de Bortoli \\ Fionn Stevenson \\ Paula Barcelos Vasconcellos}

Abstract

\section{act}

he poor initial resilience of the ground-breaking Brazilian urban social housing programme 'Minha Casa, Minha Vida'(MCMV) affects millions of people, who have tried to adapt their homes, survived the unexpected and have to reinvent themselves constantly. This study delimits the elements that compose the concept of resilience, namely: the impacts, vulnerabilities and adaptive capacities that characterize the resilience of the built environment in the case study selected. To achieve these aims, advanced Post-Occupancy Evaluation (POE) and Co-production techniques have been applied in the case study of a typical Brazilian MCMV development in Uberlandia (Brazil). The results highlighted factors going beyond the typical vulnerabilities already seen in most of these developments. They pointed out the adaptive recovery capacities as key factors for resilience. This case study provides the means to investigate resilience and its variables in depth within the specific context of MCMV's social housing, subsidising designers and public policies makers in the elaboration of more resilient projects for these social housing communities.

Keywords: Resilience. Social housing. Co-production. Post-occupancy evaluation.

${ }^{1}$ Fernando Garrefa 'Universidade Federal de Uberlândia Uberlândia - MG - Brasil

${ }^{2}$ Simone Barbosa Villa 2Universidade Federal de Uberlândia Uberlândia - MG - Brasil

${ }^{3}$ Karen Carrer Ruman de Bortoli ${ }^{3}$ Universidade Federal de Uberlândia Uberlândia - MG - Brasil

${ }^{4}$ Fionn Stevenson ${ }^{4}$ University of Sheffield Sheffield - United Kingdom

${ }^{5}$ Paula Barcelos Basconcellos ${ }^{5}$ Universidade Federal de Uberlândia Uberlândia - MG - Brasil

Recebido em 18/03/20 Aceito em 18/08/20

\section{Resumo}

A baixa resiliência inicial dos conjuntos habitacionais de interesse social (CHIS) do programa governamental 'Minha Casa, Minha Vida' (PMCMV) tem afetado milhões de brasileiros, que tentam constantemente adaptar suas casas e sobreviver ao inesperado. Este artigo tem como objetivo contextualizar na literatura o termo e suas variáveis de análise, aplicados ao estudo de CHIS do PMCMV, visando orientar intervenções capazes de aumentar sua resiliência. Este estudo delimita os elementos que compõem o conceito de resiliência, quais sejam: os impactos, vulnerabilidades e capacidades adaptativas que caracterizam a resiliência do ambiente construído no estudo de caso selecionado. Para isso, técnicas avançadas de Avaliação Pós-Ocupação (APO) e Coprodução foram aplicadas no estudo de caso de um loteamento brasileiro típico do PMCMV em Uberlândia $(M G)$. Os resultados destacaram fatores que vão além das vulnerabilidades típicas apresentadas por esses conjuntos. Demonstram a capacidade adaptativa da comunidade como um dos pilares fundamentais da resiliência. Este estudo de caso oferece os meios para investigar a resiliência e suas variáveis em profundidade no contexto específico de habitações de interesse social do PMCMC, subsidiando a formulação de projetos de CHIS mais resilientes.

Palavras-chave: Resiliência. Habitação de Interesse Social. Coprodução. Avaliação pós-ocupação. v. 21, n. 2, p. 151-175, abr./jun. 2021 


\section{Introduction}

\section{Built environment resilience}

Given the rapidly changing conditions currently caused by climate change, there is a global challenge for countries and its communities to be able to adapt and thrive in terms of improving their resilience. Globally, The New Urban Agenda (NUA) - (from the Habitat III Conference ${ }^{1}$ ) and the United Nation's SDGs (UNITED..., 2017) (Sustainable Development Goals from AGENDA 2030²), state that greater resilience is key for combating vulnerability created by the rapid growth of urban centres and inadequate urbanisation, with an objective for urban areas to "[...] adopt and implement disaster risk reduction and management, reduce vulnerability, build resilience and respond to natural and man-made hazards, and promote climate change mitigation and adaptation [...]" (UNITED..., 2017). The NUA thus includes the commitments made by the 2030 Agenda and the 2015 Sustainable Development Goals, which include the "Goal 11 - Making cities and human settlements inclusive, safe, resilient and sustainable".

The term resilience is contested and has numerous interpretations in different contexts, which require answers to the following questions: resilience for whom and for what? When? Where? And why? (MEEROW; NEWELL; STULTS, 2015). Holling (1973) was one of the first theorists to identify resilience both in terms of efficiency, constancy, and predictability as desirable attributes in fail-safe engineering and design, and also in terms of persistence, change, and unpredictability as characteristics of design that adopts failure as a form of evolution.

From Holling's conceptualization (1973), the first definition, known as Engineering Resilience, refers to a stable system, where resilience is measured by resistance against a given disturbance and the speed of return to the previous equilibrium condition. In the second definition resilience is defined by the amount of disturbance that an unstable system can absorb before transforming its own structure and being able to cope with the new situation placed, known as Ecological Resilience (HOLLING, 1973).

A review by Meerow, Newell and Stults (2015) concluded that there is no explicit definition of urban resilience within the context of the city and proposed an integrative and flexible definition for use by a variety of disciplines:

Urban resilience refers to the ability of an urban system - and all its constituent socio-ecological and socio-technical networks across temporal and spatial scales - to maintain or rapidly return to desired functions in face of a disturbance, to adapt to change, and to quickly transform systems that limit current or future adaptive capacity (MEEROW; NEWELL; STULTS, 2015, p. 2).

Resilience can also be partly defined as a state contrary to vulnerability (INSTITUTO..., 2014). According to Lemos (2014), vulnerability to climate threats, for example, refers to the sensitivity of the system infrastructure in the face of specific threats (e.g. rainfall, drought, temperature, economic crisis etc.), combined with the adaptability of the associated population and institutions, using resources available to react to the climatic event.

Based on the above and other studies, the broader concept of resilience adopted in this study is the capacity of the built environment of resisting, adapting and transforming itself to deal with changes or impacts imposed over time (PICKETT et al., 2014; HASSLER; KOHLER, 2014; GARCIA; VALE, 2017). These impacts are incident under natural-climatic, physical, social-economic and socio-technical orders with demands, that over time, become a critical urban agenda. According to Garcia and Vale (2017), to improve the resilience of a system "[...] you need to know where it is starting from - which means measuring something - and you need to know where it is going, which means tracing future possibilities [...]". It is important to know the changes, here considered as impacts, that affect the system under study, observing their repercussions: whether it originates adaptive capacities or vulnerabilities (or both), being these the main concepts considered in this study. Figure 1 summarizes these resilience concepts synthesised from various articles (BORTOLI, 2018; GARCIA; VALE, 2017; RODIN, 2015; PICKETT et al., 2014; HASSLER; KOHLER, 2014; LEMOS, 2014; DAVOUDI; CRAWFORD; MEHMOOD, 2009; MAGUIRE; CARTWRIGHT, 2008).

1Source: http://habitat3.org/the-new-urban-agenda/. Accessed in: Aug. 2020.

2Source: https://sustainabledevelopment.un.org/post2015/transformingourworld. Accessed in: Aug. 2020.

152 Garrefa, F.; Villa, S. B.;, K. C. R. de; Stevenson, F.; Vasconcellos, P. B. 
Figure 1 - Synthesised resilience concepts

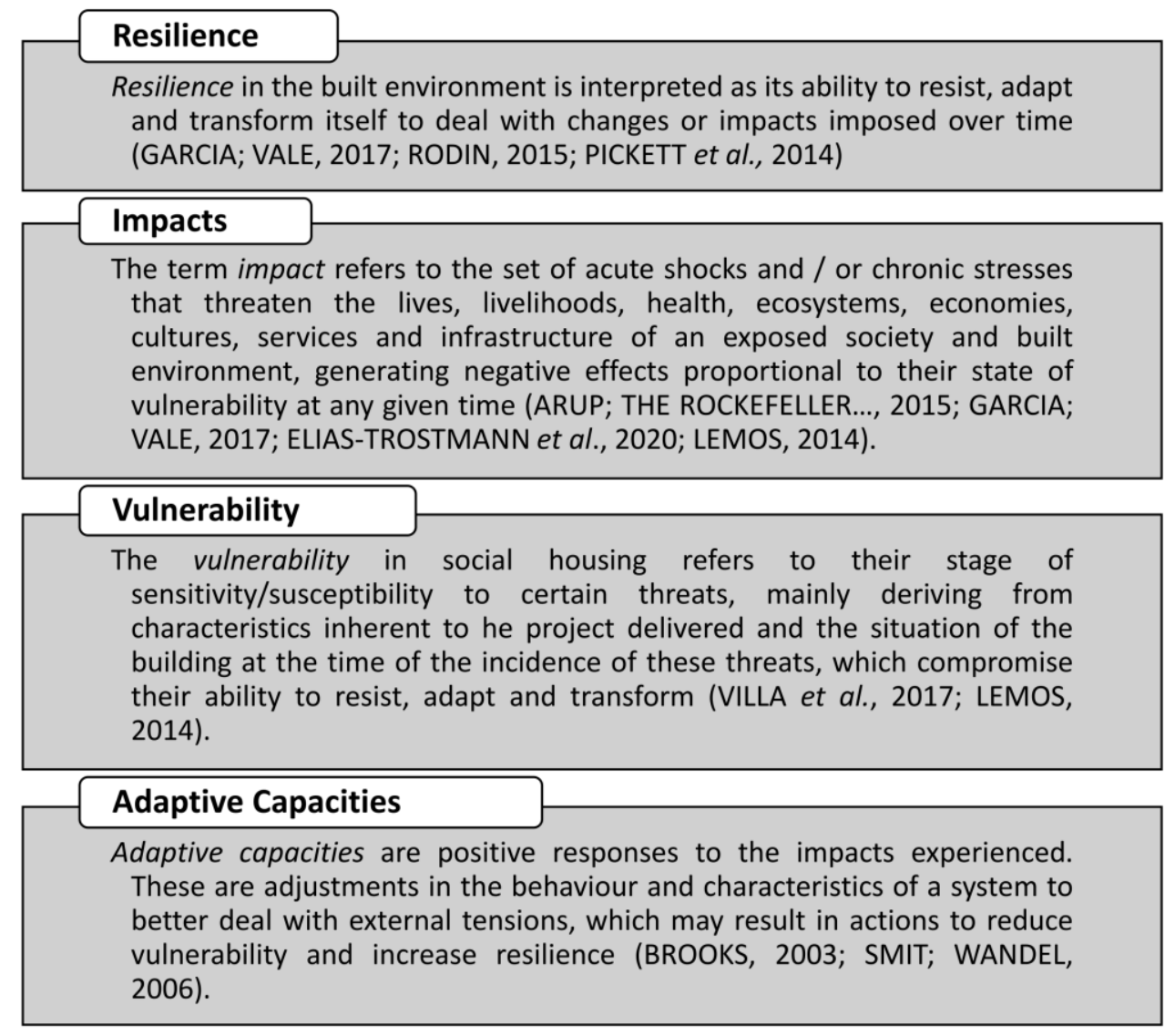

Within the rapid urbanization processes in Brazil, the resultant low quality of architecture and urbanism increases the social vulnerability impacting millions of people, especially those in search of housing (Villa et al., 2017). This is about daily negative incremental impacts on social, economic and environmental factors, which are extremely harmful in the long run and even worse for the lower classes. Specifically within the social housing context, the peripheralization of the complexes and the poor construction quality of the housing units are some of the issues that significantly interfere with its resilience, as described below (VILLA; OLIVEIRA; SARAMAGO, 2013; MARICATO, 2000; CABRITA, 1995).

\section{Minha Casa, Minha Vida Programme}

From 1940-2010, the Brazilian urbanisation rate increased from $40 \%$ to over $85 \%$, with 165 million people leaving rural areas and moving to cities (UNITED..., 2011). The government responded by delivering millions of new housing units through its low-income programme "Minha Casa, Minha Vida" (MCMV) initiated in 2009 as an attempt to reduce the national housing deficit.

MCMV represents an industrial-scale production logic pursued by large companies that ignores any guiding principles for the design processes that develop from specific contexts, as demonstrated in the similarity of products delivered across very different regions of Brazil (RUFINO, 2015).

The standard house comprises of just $32 \mathrm{~m}^{2}$, containing a living room, two bedrooms, a bathroom, kitchen and outside laundry (Figure 2), with poor capacity to adapt to vulnerabilities and changes during its use. The poor housing resilience is due to low quality materials and finishing techniques with no consideration of the transformations in the family group over time or the possibility of using housing as a place of work (VILLA; SARAMAGO; GARCIA, 2015).

The location of MCMV developments is generally decided according to the interests of the municipality, entrepreneurs and land owners, rather than the inhabitants (HIRATA, 2009). This marginalization increases their social and environmental vulnerability (VILLA; OLIVEIRA; SARAMAGO, 2013) and compromises resilience (VILLA et al., 2017) by locating homes far from the city centre making inhabitants highly 
dependent on individual automotive transport. PMCMV developments generally lack paved streets, public transportation, educational and health facilities, overloading the existing public transport system which cannot cope with this situation where peripheral inhabitants have to travel to the city centre for these facilities (SHIMBO; CERON, 2014).

This U\$950 billion programme has provided housing for a significant population while boosting the country's economy. However, it has failed to provide to Brazilians the quality homes they need and desire (ANGÉLIL; HEHL, 2014). The 4.44 million delivered housing units are poorly located (BIDERMAN et al., 2019) and require a retrofit solution. An audit by the Federal Court of Audit on MCMV housing developments, released in 2018 , found that " $73.4 \%$ of residents suffer from a lack of schools and day care centres within the vicinity; $70.2 \%$ say they have no basic health unit; $68.1 \%$ do not have commercial facilities close by; and $46.8 \%$ consider public transportation insufficient". Figure 3 presents additional problems associated with the low quality of delivered social housing.

The housing model and application of minimum urban specifications demonstrate a poor orientation to resilience, making it difficult to resist, adapt and/or transform over time. To optimize resources for the production and maintenance of this housing, and deal with the identified problems, it is necessary to invest carefully in the resilience of existing housing stock, by identifying the most effective measures.

Given these significant challenges, this paper evaluates the resilience of an MCMV social housing complex as a case study of the "Shopping Park" project in the outskirts of the medium sized city of Uberlândia Brazil. This case study provides the means to investigate resilience and its variables in depth within the specific context of MCMV's social housing, allowing potential generalisations (FLYVBJERG, 2006).

Thus, the general objective of the presented study is:

(a) to analyse the resilience in social housing developments from the evidence of a case study in Uberlândia-Brazil;

(b) the specific objectives are:

- to research and delimit elements that compose the concepts of resilience within the case study; and

- to analyse the impacts, vulnerabilities and adaptive capacities that characterise the resilience of the built environment in the case study presented.

Figure 2 - House unit typology

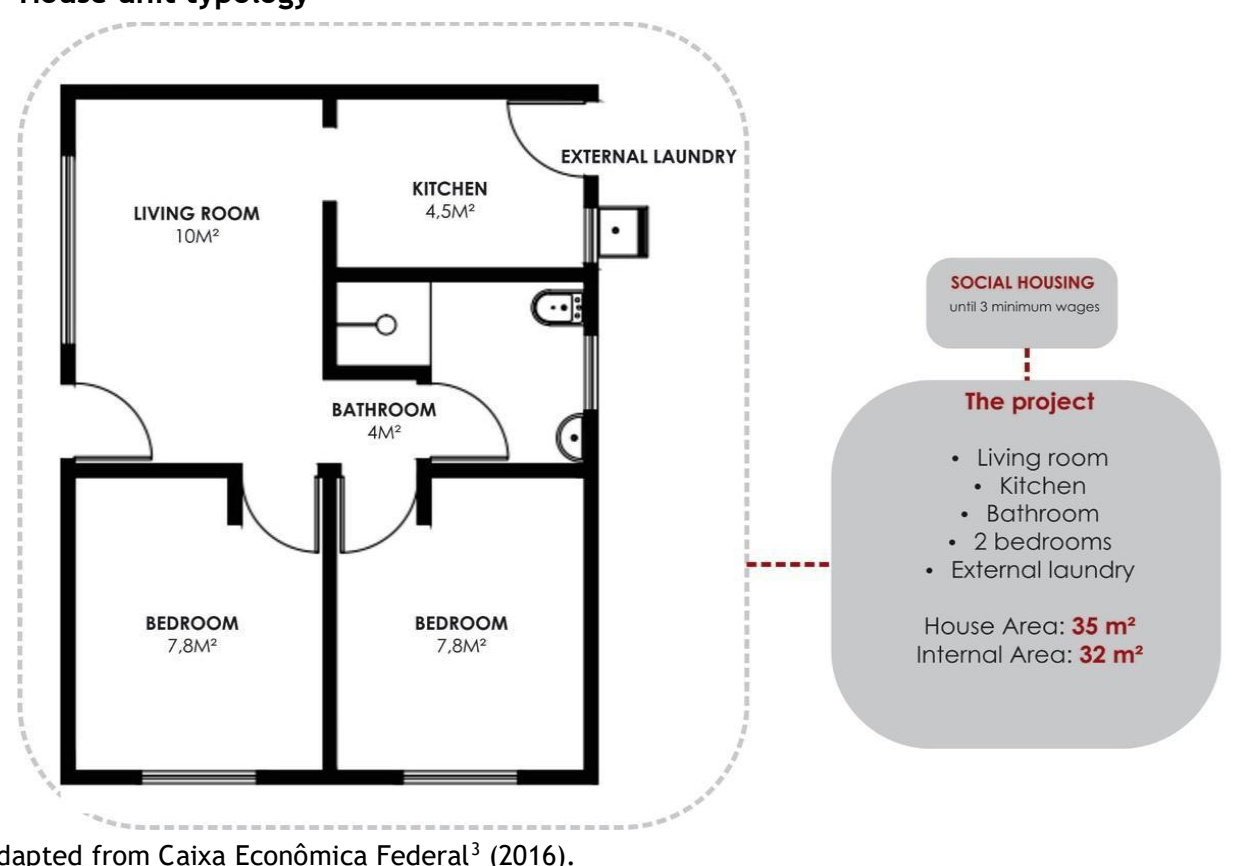

Source: adapted from Caixa Econômica Federal ${ }^{3}$ (2016).

${ }^{3}$ Available at: http://www.caixa.gov.br/. Accessed in: Aug. 2020.

154 Garrefa, F.; Villa, S. B.;, K. C. R. de; Stevenson, F.; Vasconcellos, P. B. 
Figure 3 - Problems on individual housing units

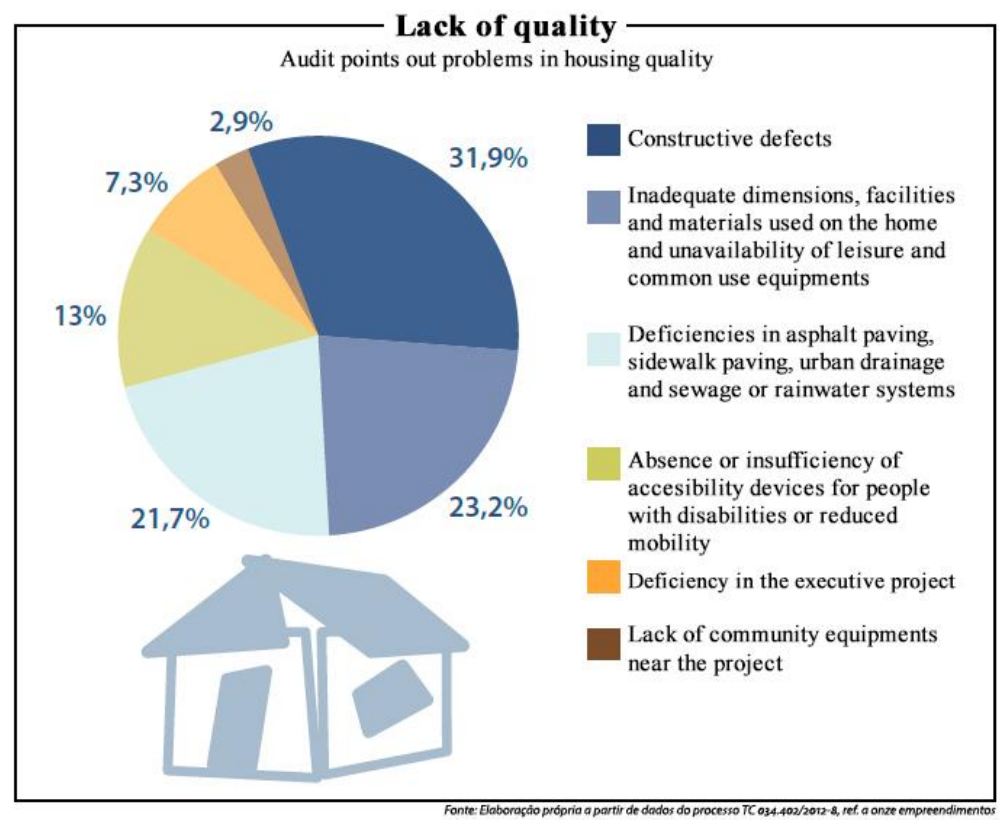

Source: adapted form TCU - Federal Court of Audit ${ }^{4}$ (2018).

The paper presents the mixed methods used to evaluate the impacts, vulnerabilities and adaptive capacities, which describe the overall resilience of the built environment in the study case area, and the resultant findings which define an intervention process and potential interventions.

\section{Methods}

\section{Selection of research methods}

The research project started from a literature review on the themes of MCMV and resilience, aiming to support the studies. From this review, we took the option for the categorisation in 5 different aspects adapted by the authors from previous studies ${ }^{5}$ as follows:
(a) General Characteristics;
(b) Climatic Natural Order;
(c) Physical-Architectonic Order;
(d) Physical-Urbanistic Order and; and
(e) Socioeconomic Order (Table 1).

The Shopping Park complex was chosen due to its complexity and size, with over 3,000 housing units for low income people built from 2010-2012, under the MCMV programme.

After the choice of the 5 aspects and the location, a mixed methods approach was used for the case study system. To understand the complex problems in the area of environment and behaviour, both quantitative and qualitative methods are used in this approach. According to Mallory-Hill, Preiser and Watson (2012, p. 3) post-occupancy evaluation (POE) "[...] can be used to identify and correct problems in individual buildings and the lessons derived from the successes and failures of many buildings can be used to inform the planning, programming, design and management of future buildings [...]". POE can also be used to identify existing levels of resilience within social housing communities (STEVENSON; BARBORSKA-

\footnotetext{
${ }^{4}$ Available at: https://www12.senado.leg.br. Accessed in Aug. 2020.

${ }^{5}$ The [MORA] Housing research group has been developing this classification since 2016 throughout the research "[RES_APO 1] Method of analysis of the Resilience and Adaptability in Social Housing Complexes through Post Occupancy Evaluation and Co-production", which could be seen at https://morahabitacao.com/pesquisas/.
} 
NAROZNY; CHATTERTON, 2016) from which to develop recommendations and proposed interventions to increase their resilience.

Co-production has been defined as "[...] delivering public services in an equal and reciprocal relationship between professionals, people using services, their families and their neighbours [...]" (BOYLE; HARRIS, 2009 , p. 11). However, other definitions of co-production explicitly question the production processes which generate social injustice and inequality in urban environments (MAGUIRE; CARTWRIGHT, 2008) which are arguably "[...] central to the process of developing a 'core economy' that can generate a more responsive process towards developing social as well as physical resilience.” (STEVENSON; PETRESCU, 2016, p. 695). This study draws explicitly on the co-production approach set out by the latter two sets of authors, considering Co-production as a qualitative and participative evaluation method where a facilitator coproduces management of a place by all stakeholders by addressing unmet public demands (PETCOU; PETRESCU, 2015). This collaborative action technique treats the researcher as a facilitator in the process of production and space management by the users involved. Here, the mediation of the researcher (academics, architects, planners) allows for more partnerships and broader and more effective community participation. The projects, more than simply seeking a specific result of physical transformation, manage, during the process, to contribute to the social and political emancipation of the users working in this space.

The co-productions seek a closer relationship with the community, since to assess resilience and its indicators, it is necessary to connect with those who exercise it empirically (MEEROW; NEWELL; STULTS, 2015), which means understanding the residents' vision and identifying key problems in housing units - through group discussions, dynamics, mapping activities, workshops, among others. Within this methodological context, Co-production acts as a tool that complements the POE, providing a scenario for more in-depth observation of subjective factors and issues raised in the application of questionnaires that need to be verified. Therefore, Co-production as a research approach, together with POE evidence (questionnaires, walkthroughs, performance evaluation), offers a means to challenge and change the power relationships inherent in the built environment, its production, governance and maintenance, in order to enable more sustainable and resilient communities.

POE tools were selected to analyse three central elements in the case study:

(a) built environment;

(b) external agents; and

(c) inhabitants, in order to explore the resilience in the housing development.

These three elements were refined into five categories: general characteristics, climatic and natural order, physical-architectonic order, physical-urbanistic order and socioeconomic order, as summarised in Table 1.

Tools were then selected to collect information for each urban category in order to understand the resilience challenges identified more deeply in terms of impacts, vulnerabilities and adaptive capacities related to each category. For example, the physical-architectonic order was subdivided into 10 aspects to be evaluated and measured using different methods (Table 2). The other four orders used a similar process.

Table 1 - Urban Categories for Resilience Evaluation

\begin{tabular}{|c|l|l|}
\hline Stage & \multicolumn{1}{|c|}{ Addressed Aspect } & \multicolumn{1}{c|}{ Description } \\
\hline 1 & General Characteristics & $\begin{array}{l}\text { State of the art, description of the housing programme, general } \\
\text { characteristics of the city of Uberlândia and the study subject; }\end{array}$ \\
\hline 2 & $\begin{array}{l}\text { Climatic Natural Order } \\
\text { (Environmental } \\
\text { Resilience) }\end{array}$ & $\begin{array}{l}\text { Vegetation, soil, water sources, flows, weather statistics, } \\
\text { pollution, waste, topography, shortages (water, power, food), } \\
\text { stretched dry seasons, warmer; }\end{array}$ \\
\hline 3 & $\begin{array}{l}\text { Physical-Architectonic } \\
\text { Order (Housing } \\
\text { Resilience) }\end{array}$ & $\begin{array}{l}\text { Format, construction system and materials, services (electricity, } \\
\text { water, sewage, IT/electronics, cost+supply), internal layout, } \\
\text { adaptation; }\end{array}$ \\
\hline 5 & $\begin{array}{l}\text { Physical-Urbanistic Order } \\
\text { (Neighbourhood } \\
\text { Resilience) }\end{array}$ & $\begin{array}{l}\text { Land-use, social facilities (leisure, sport, culture, safety, security), } \\
\text { infrastructure, transport, density, commerce/business (income } \\
\text { generation), violence, food (agro city), income; }\end{array}$ \\
\hline 5 & $\begin{array}{l}\text { Socioeconomic Order } \\
\text { Social Resilience) }\end{array}$ & $\begin{array}{l}\text { Demographics, social-economic data-analysis, violence, safety, } \\
\text { policy, NGO's (3RD sector), education, health, other agents. }\end{array}$ \\
\hline
\end{tabular}

156 Garrefa, F.; Villa, S. B.;, K. C. R. de; Stevenson, F.; Vasconcellos, P. B. 
Table 2 - Physical-architectonic order - perceptions and technical information - aspects evaluated, information evaluated and its tools

\begin{tabular}{|c|c|c|}
\hline \multicolumn{3}{|c|}{ Physical-Architectonic Order } \\
\hline Aspects & Data collection & Methods \\
\hline \multirow{2}{*}{$\begin{array}{l}\text { Design (format, } \\
\text { dimensions) }\end{array}$} & General information - plants, documents, measurements. & Desk research \\
\hline & The main problems in the home (by priority). & Questionnaire \\
\hline \multirow{4}{*}{$\begin{array}{l}\text { Construction } \\
\text { system and } \\
\text { materials }\end{array}$} & General information - plants, documents, measurements. & Desk research \\
\hline & Identifying construction pathologies. & $\begin{array}{l}\text { Performance evaluation } \\
\text { Walkthrough }\end{array}$ \\
\hline & $\begin{array}{l}\text { The main constructive pathologies of the home } \\
\text { Materials used in the home (level of satisfaction) } \\
\text { Availability in neighbourhood of materials used in the } \\
\text { home construction. }\end{array}$ & Questionnaire \\
\hline & Materials used in the renovation of the home. & $\begin{array}{l}\text { Co-production (group } \\
\text { discussion - housing scale) }\end{array}$ \\
\hline \multirow[b]{2}{*}{ Maintenance } & Identifying aspects of maintenance. & Walkthrough \\
\hline & $\begin{array}{l}\text { Assessment of home maintenance and problems. Level of } \\
\text { satisfaction and open space. }\end{array}$ & Questionnaire \\
\hline $\begin{array}{l}\text { Services } \\
\text { (electricity, } \\
\text { water, sewage, } \\
\text { IT/electronics, } \\
\text { cost+supply) } \\
\end{array}$ & $\begin{array}{l}\text { General information - documents, measurements } \\
\text { Inhabitant use of services and decision making. } \\
\text { Use of equipment (microwave, light, electric shower, } \\
\text { washing machine, iron, computer, hair dryer, etc.) time, } \\
\text { power rating. }\end{array}$ & $\begin{array}{l}\text { Desk research } \\
\text { Performance evaluation } \\
\text { Walkthrough }\end{array}$ \\
\hline \multirow{3}{*}{$\begin{array}{l}\text { Internal layout - } \\
\text { functionality }\end{array}$} & General information - plants, documents, measurements. & Data collection \\
\hline & $\begin{array}{l}\text { Activities in the home } \\
\text { (to sleep, to cook, to feed, work, stock, to relax, socialize, } \\
\text { live together, sanitize, to exercise, etc). Level of } \\
\text { satisfaction and open space. }\end{array}$ & $\begin{array}{l}\text { Questionnaire } \\
\text { Co-production (group } \\
\text { discussion - housing scale) }\end{array}$ \\
\hline & $\begin{array}{l}\text { Furniture and equipment existing in the home } \\
\text { Furniture needed in the home. }\end{array}$ & $\begin{array}{l}\text { Questionnaire } \\
\text { Co-production (group } \\
\text { discussion - housing scale) }\end{array}$ \\
\hline \multirow{2}{*}{$\begin{array}{l}\text { Adaptation } \\
\text { refurbishment }\end{array}$} & $\begin{array}{l}\text { Adaptation of house to the needs of the family. } \\
\text { Types of refurbishment/changes made, } \\
\text { Difficulties in refurbishing/changing the home. Why? }\end{array}$ & $\begin{array}{l}\text { Questionnaire } \\
\text { Co-production (group } \\
\text { discussion - housing scale) } \\
\end{array}$ \\
\hline & $\begin{array}{l}\text { Future vision for the home. } \\
\text { Home improvements for income generation. }\end{array}$ & $\begin{array}{l}\text { Co-production (dynamic } \\
\text { "what I have/what I want" - } \\
\text { housing scale) }\end{array}$ \\
\hline $\begin{array}{l}\text { Adaptation for } \\
\text { commerce }\end{array}$ & $\begin{array}{l}\text { Income-generating activity in home. } \\
\text { How is space adapted for this purpose. }\end{array}$ & $\begin{array}{l}\text { Questionnaire } \\
\text { Co-production (group } \\
\text { discussion - housing scale) }\end{array}$ \\
\hline \multirow[t]{3}{*}{$\begin{array}{l}\text { Comfort } \\
\text { (noise, } \\
\text { temperature, } \\
\text { humidity, light) }\end{array}$} & $\begin{array}{l}\text { Home: } \\
\text { TEMPERATURE (winter/summer/night/day) - very hot, } \\
\text { hot, normal, cold, very cold. Indicate the extremes in } \\
\text { rooms. } \\
\text { NOISE (internal, external) - very noisy, loud, normal, } \\
\text { quiet, very quiet. Indicate the extremes in rooms } \\
\text { NATURAL LIGHTING - very bright, bright, normal, } \\
\text { dark, very dark. Indicate the extremes in rooms } \\
\text { HUMIDITY - very humid, humid, normal, dry, very dry. } \\
\text { Indicate the extremes in rooms. }\end{array}$ & $\begin{array}{l}\text { Performance evaluation } \\
\text { Questionnaire }\end{array}$ \\
\hline & Greatest cause of discomfort in the home. Why? & Questionnaire \\
\hline & What makes a home comfortable or uncomfortable. & $\begin{array}{l}\text { Co-production (group } \\
\text { discussion - housing scale) }\end{array}$ \\
\hline Privacy & $\begin{array}{l}\text { Privacy in home. (Level of satisfaction). } \\
\text { Privacy in relation to your neighbours. (Level of } \\
\text { satisfaction). }\end{array}$ & $\begin{array}{l}\text { Questionnaire } \\
\text { Co-production (mapping } \\
\text { activity "positive/negative } \\
\text { points" - housing scale) }\end{array}$ \\
\hline $\begin{array}{l}\text { Previous } \\
\text { housing }\end{array}$ & $\begin{array}{l}\text { Describe and assess your previous housing: kind, size, } \\
\text { construction quality, comfort, location, cost, maintenance. }\end{array}$ & Questionnaire \\
\hline
\end{tabular}




\section{Tools and techniques}

After the initial secondary physical data collection phase, a customized social POE approach was developed combining Questionnaires, Walkthroughs and Co-production methods (Table 3) based on Leaman, Stevenson and Bordass' guidance for BPE (2010). The Co-production sessions with the inhabitants provided opportunities to further investigate resilience aspects revealed by other methods.

The case study was sampled from a large social housing complex, the Residencial Shopping Park. It is the largest social housing development ever built in the city of Uberlândia, MG. Located in the southern sector of the city, the area was used to produce more than 3.000 single-storey housing units under the Minha Casa Minha Vida Programme. Within this scenario, one allotment (Residencial Sucesso Brasil) was selected as a representative detailed area for analysis within the case study area, due to its central position and proximity in relation to the main facilities (Figure 4).

\section{Analysis}

\section{Case study general characteristics}

The following paragraphs present the general characteristics of the city of Uberlândia and the study subject, mainly obtained from desk research on public data and previous fieldwork reports performed by the authors.

Uberlândia has a climate characterized by a wet season (October-March), and a dry season - (AprilSeptember) (PETRUCCI, 2018) (Figure 5). The housing units are perpendicular to the slope of 12\%, within highly impervious ground surfaces, a lack of adequate containment waterproofing, soil drainage solutions and vegetation, making the houses structurally vulnerable to the effects of landslides, with little resilience in relation to rainfall (Figure 6) (VILLA et al., 2017).

The vulnerable Shopping Park neighbourhood shows a fragmented road network that isolates it from the city and its facilities. The bus timetables are inefficient, with waiting times around one to two hours and infrequent bus stops which do not meet the demand (VILLA et al. 2017). The existent cycle paths are also vulnerable, being made from low-quality materials and with poor signage, making it difficult for inhabitants to identify them. They also have poor connection and continuity within the transport system (Figures 7 and 8). All of this demonstrates a transport infrastructure with very little resilience built into it.

Table 3 - Methods used to evaluate Shopping Park Neighbourhood

\begin{tabular}{|c|c|c|}
\hline Questionnaire & Walkthrough & Co-production \\
\hline $\begin{array}{l}\text { DESCRIPTION: A } \\
\text { quantitative method that } \\
\text { seeks to collect data from a } \\
\text { series of questions answered } \\
\text { by inhabitants in a large } \\
\text { group. Anonymity allows } \\
\text { safety, freedom of response } \\
\text { and greater uniformity in the } \\
\text { evaluation. }\end{array}$ & $\begin{array}{l}\text { DESCRIPTION: Quanti- } \\
\text { qualitative method of analysis } \\
\text { based on quality concerns for } \\
\text { measuring and descriptive } \\
\text { and qualitative identification } \\
\text { of positive and negative } \\
\text { aspects of the environment } \\
\text { concerning }\end{array}$ & $\begin{array}{l}\text { DESCRIPTION: Qualitative and } \\
\text { participative evaluation method where } \\
\text { a facilitator co-produces management } \\
\text { of a place by all stakeholders by } \\
\text { addressing unmet public demands } \\
\text { (PETCOU; PETRESCU, 2015). A co- } \\
\text { productive partnership between } \\
\text { academics and non-academics can } \\
\text { generate significant public benefits. }\end{array}$ \\
\hline $\begin{array}{l}\text { MEANS: Digital } \\
\text { questionnaire }\end{array}$ & $\begin{array}{l}\text { MEANS: Text and } \\
\text { photographic recording. }\end{array}$ & $\begin{array}{l}\text { MEANS: text and photographic } \\
\text { recording, meetings and workshops. }\end{array}$ \\
\hline $\begin{array}{l}\text { SAMPLE: } 40 \text { houses }(22 \% \\
\text { of the whole community of } \\
175 \text { homes in one housing } \\
\text { block). }\end{array}$ & $\begin{array}{l}\text { SAMPLE: } 4 \text { representative } \\
\text { homes, with varying } \\
\text { orientations and locations } \\
\text { with the housing block. }\end{array}$ & $\begin{array}{l}\text { SAMPLE: Residents of the block } \\
\text { invited and snowballing. } 15 \text { per session } \\
\text { on average. }\end{array}$ \\
\hline DATE: July $5^{\text {th }}$ to $11^{\text {th }}, 2016$ & DATE: July $8^{\text {th }}$ and $11^{\text {th }}, 2016$ & $\begin{array}{l}\text { DATES: } 2017 \text { - July } 9^{\text {th }} \text { (Collective } \\
\text { Coffee), August } 7 \text { th (II Meeting Renew } \\
\text { Shopping Park) and October } 12^{\text {th }} \text { (III } \\
\text { Meeting Renew Shopping Park) }\end{array}$ \\
\hline $\begin{array}{l}\text { RESPONDENTS: Shopping } \\
\text { Park Neighbourhood's } \\
\text { inhabitants }\end{array}$ & $\begin{array}{l}\text { RESPONDENTS: Technical } \\
\text { evaluators in research team. }\end{array}$ & $\begin{array}{l}\text { RESPONDENTS: Inhabitants and } \\
\text { research team. }\end{array}$ \\
\hline
\end{tabular}

158 Garrefa, F.; Villa, S. B.;, K. C. R. de; Stevenson, F.; Vasconcellos, P. B. 
Figure 4 - Location of shopping park social complex and the residencial Sucesso Brasil housing units
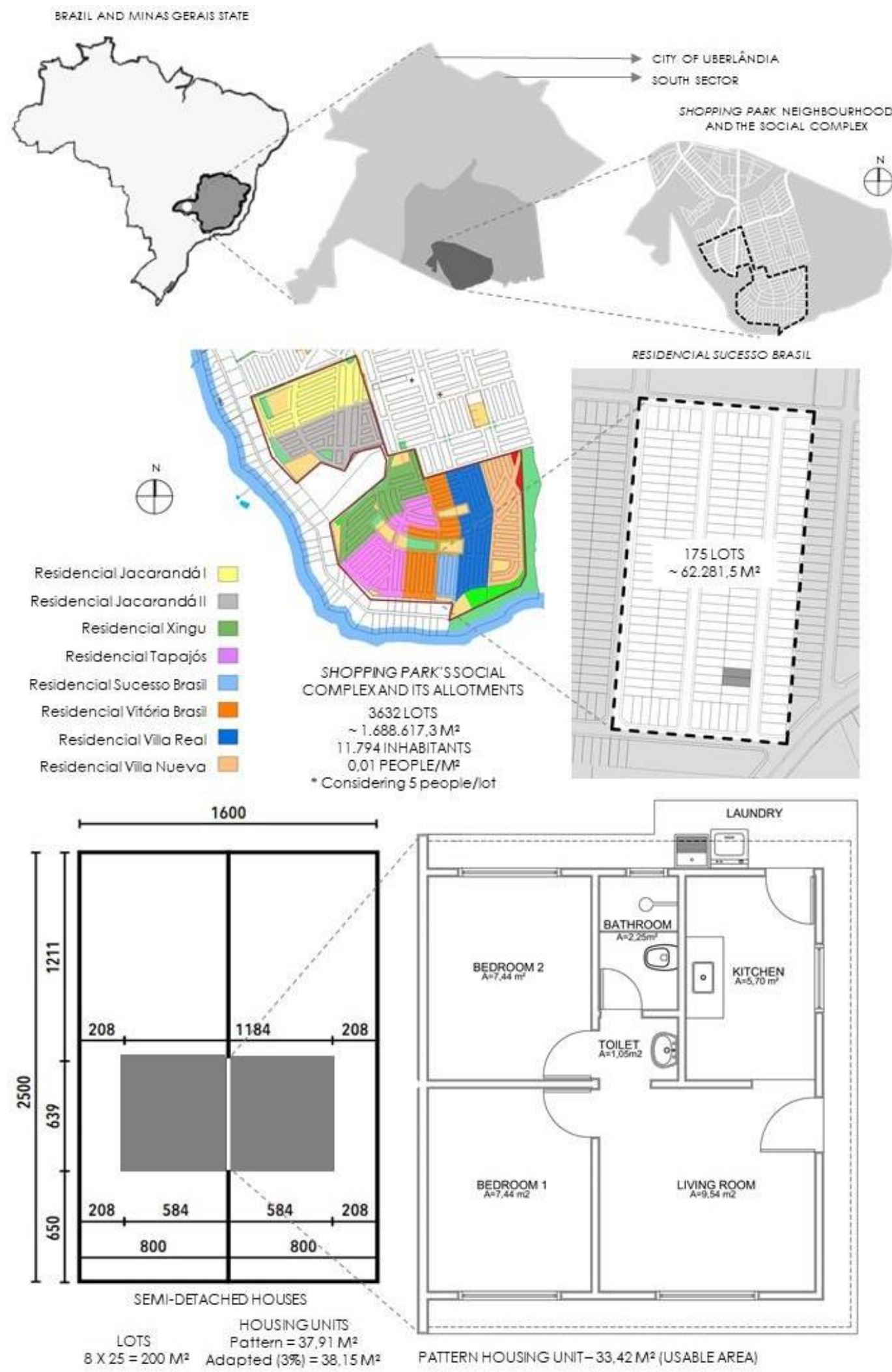

Source: Villa et al. (2017) provided by the city hall of Uberlândia in 2016 (with alterations). 
Figure 5 - General data about Uberlândia and of Shopping Park social complex

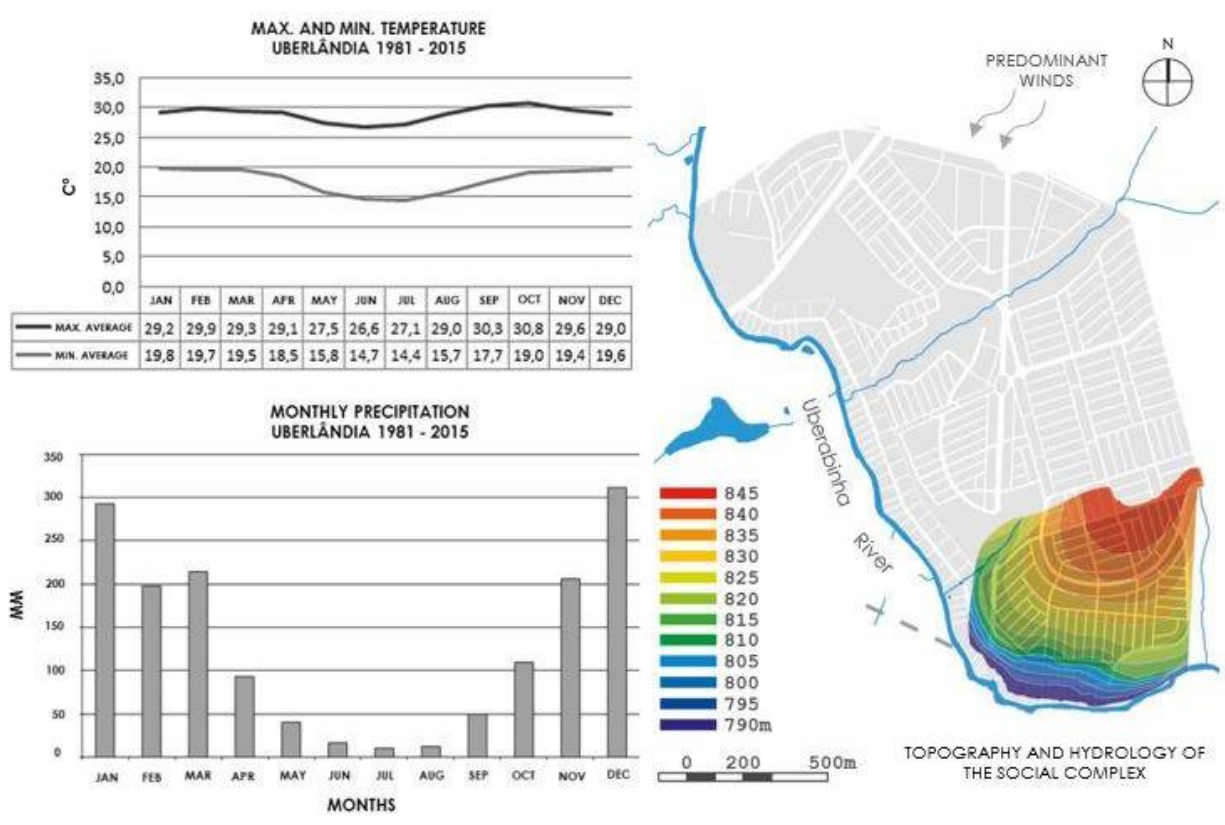

Figure 6 - Block settlement and landslide accident
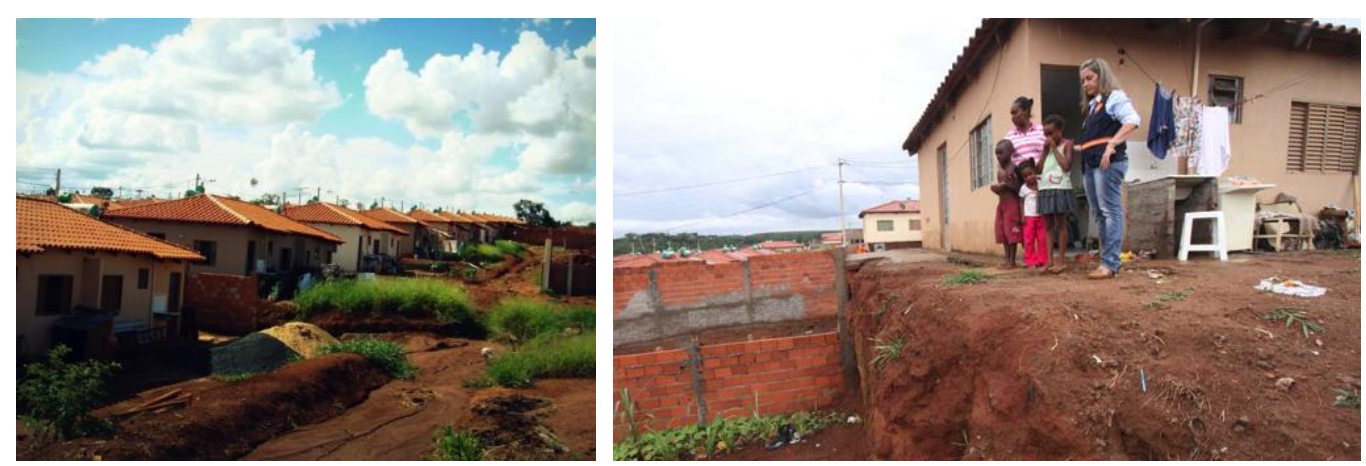

Figure 7 - Urban mobility at the neighbourhood and in the social complex
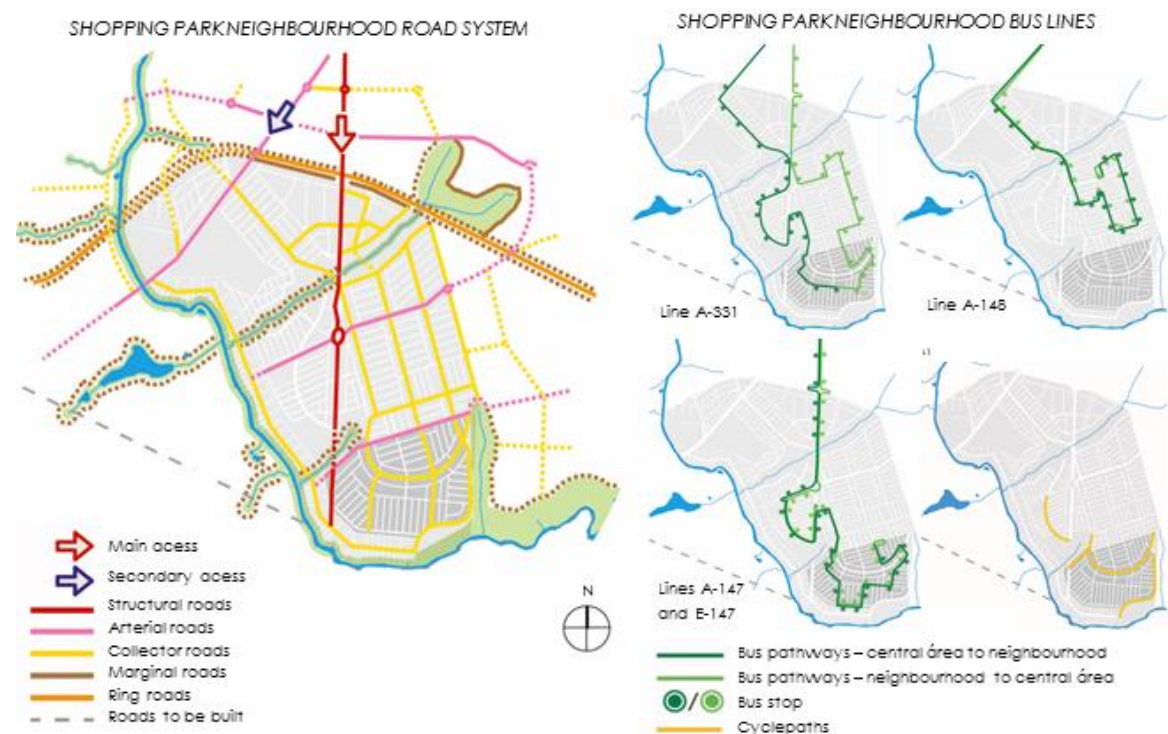

Source: Villa et al. (2017) provided by the city hall of Uberlândia in 2016 (with alterations).

160 Garrefa, F.; Villa, S. B.;, K. C. R. de; Stevenson, F.; Vasconcellos, P. B. 
Figure 8 - Shopping Park neighbourhood cycle paths

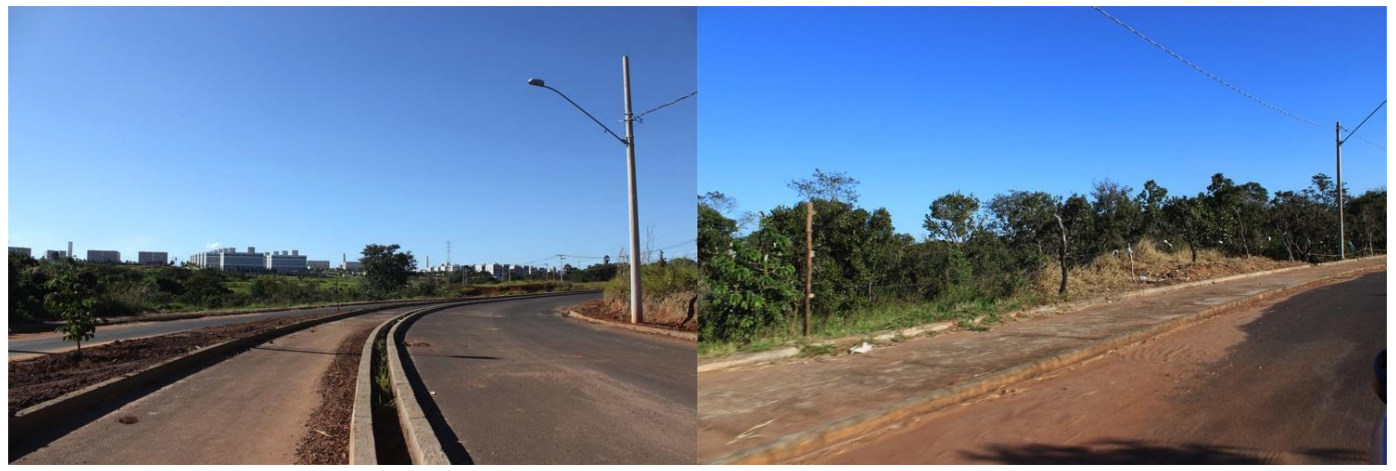

Figure 9 - Land use and facilities in the neighbourhood

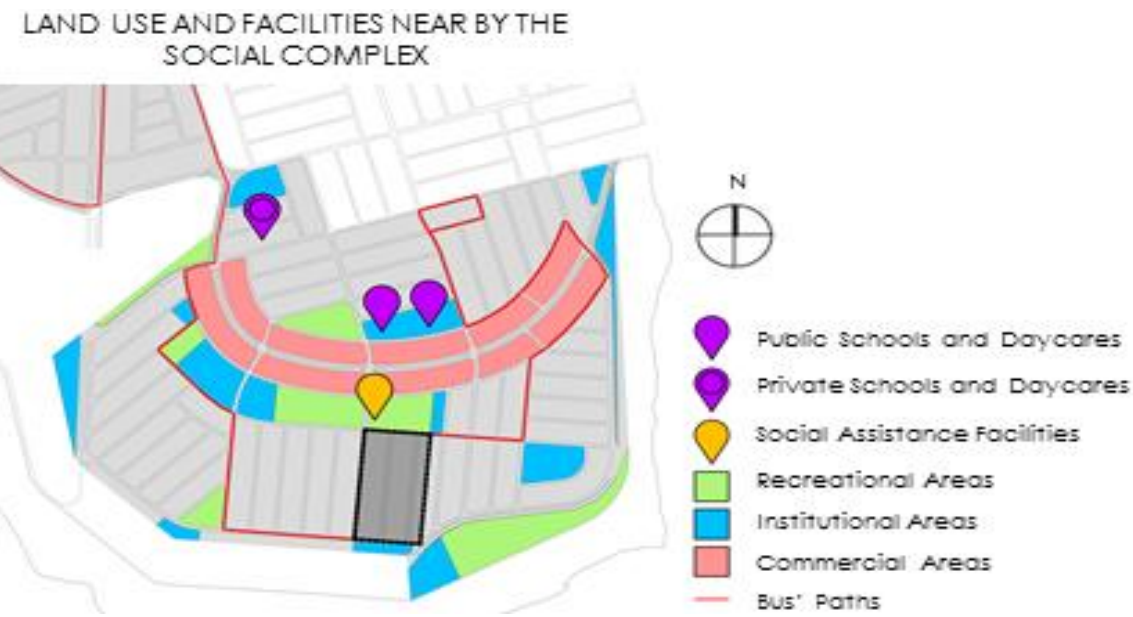

Source: Villa et al. (2017) provided by the city hall of Uberlândia in 2016 (with alterations).

\section{Figure 10 - Adapted residential commerce and service activities}

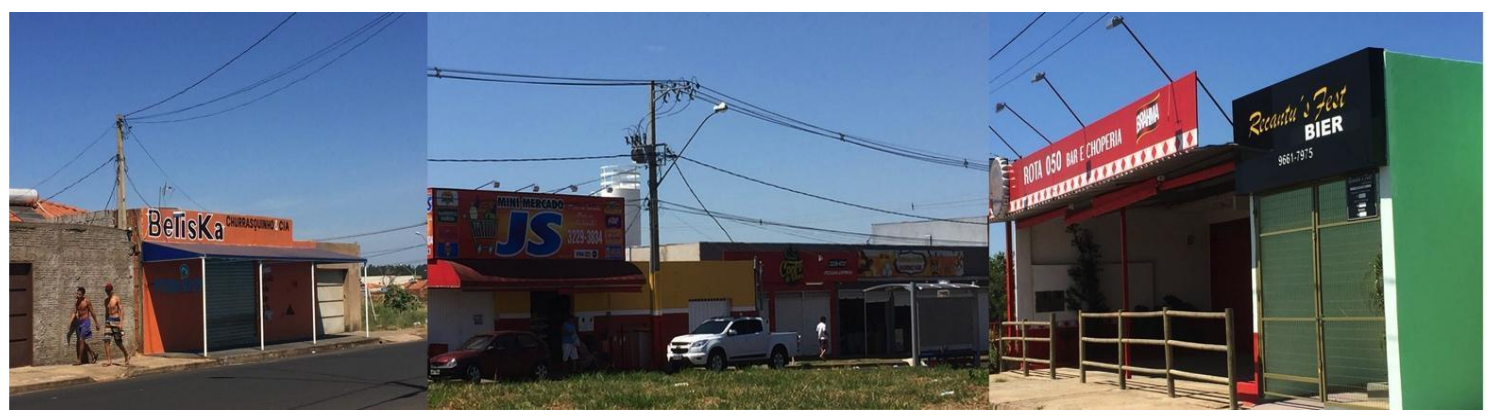

The main avenues were originally planned as commercial and institutional, adjacent to strictly residential areas (Figure 9). However, they do not connect to arterial roads which are needed to service commercial activities (VILLA et al. 2017). The complex thus lacks vital commercial amenities for resilience such as food outlets. The price of the commercial land is also unaffordable for the low-income families. There is also a scarcity of educational, social assistance and health facilities in the neighbourhood (Figure 9) apparently reducing social resilience. However, due to denser pedestrian flows closer to the houses, numerous informal commercial and social outlets such as repair workshops, daycare centers, hairdressers and food shops have developed in the residential areas, showing a strong social resilience developing within the local community.

Housing has been adapted for retail and social services, as either individual or joint units. This typology has spread over the residential area, demonstrating that this hybrid housing typology has a certain degree of adaptability (Figure 10). 
The next section discusses the vulnerabilities and adaptive capacities of the overall neighbourhood, according to its resilience capabilities as identified through the analysis.

The results were organized into four key dimensions that express scales of analysis and intervention in social housing. These key dimensions are directly derived from the observation of the 'aspects addressed' in the case study's reality (Table 1, topic 2.1). They point out the focuses of our attention on each aspect studied, aiming at the implementation of resilience. Are they: environmental resilience (related to the ClimaticNatural Order of analysis), housing resilience (related to the Physical-Architectonic Order), neighbourhood resilience (Physical-Urbanistic Order) and social resilience (Socioeconomic Order).

\section{Environmental resilience}

The main environmental vulnerabilities and adaptive capacities of the Shopping Park neighbourhood are set out in Table 4.

Table 4 - Environmental vulnerability and adaptation

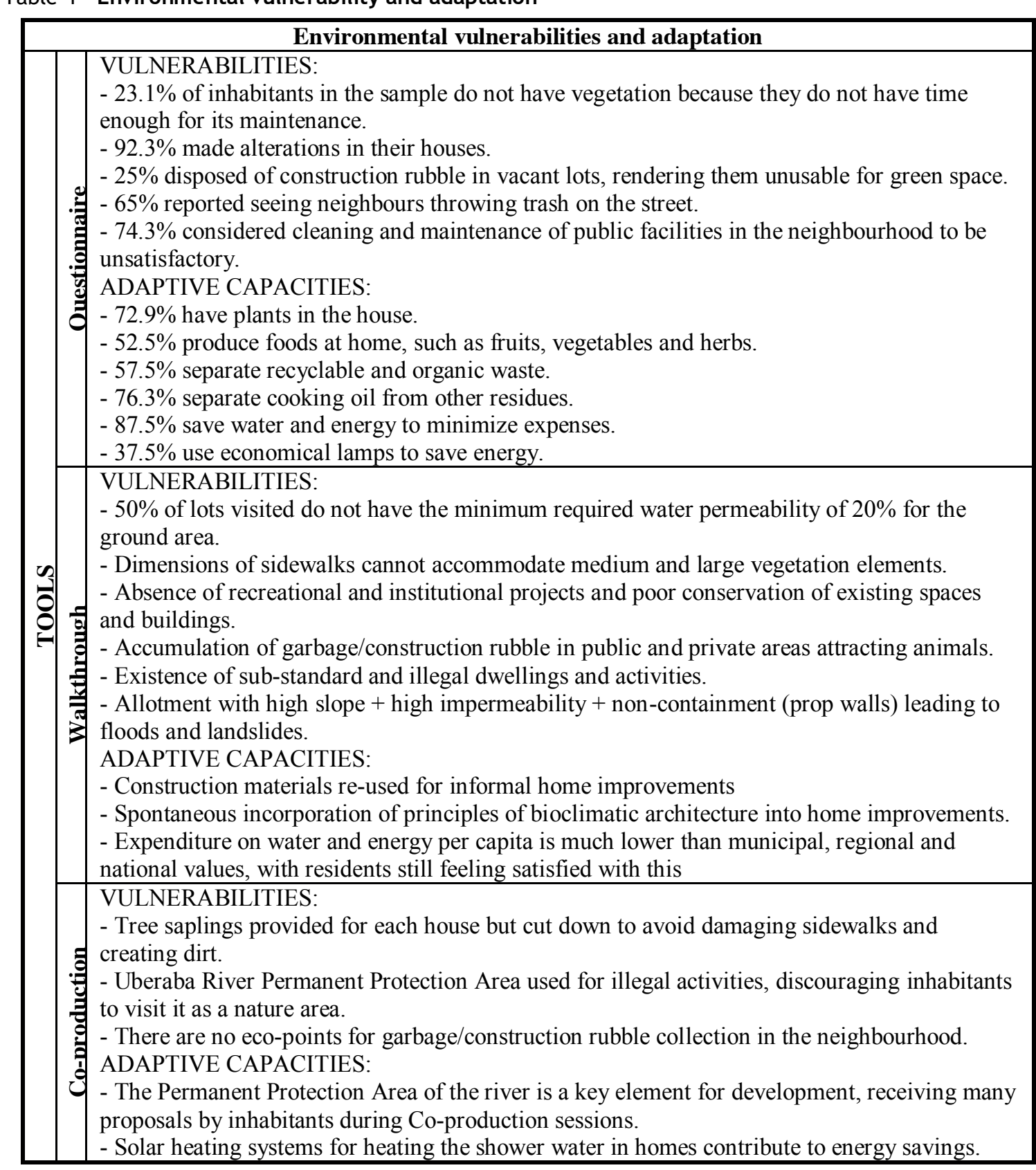

162 Garrefa, F.; Villa, S. B.;, K. C. R. de; Stevenson, F.; Vasconcellos, P. B. 
Figura 11 - Environmental resilience factors

\section{ENVIRONMENTAL RESILIENCE}

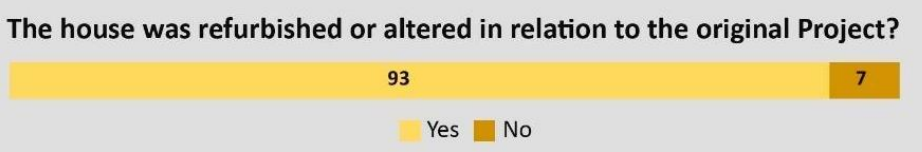

\section{ALTERATIONS/ REFURBISHMENTS/ PERMEABILITY}

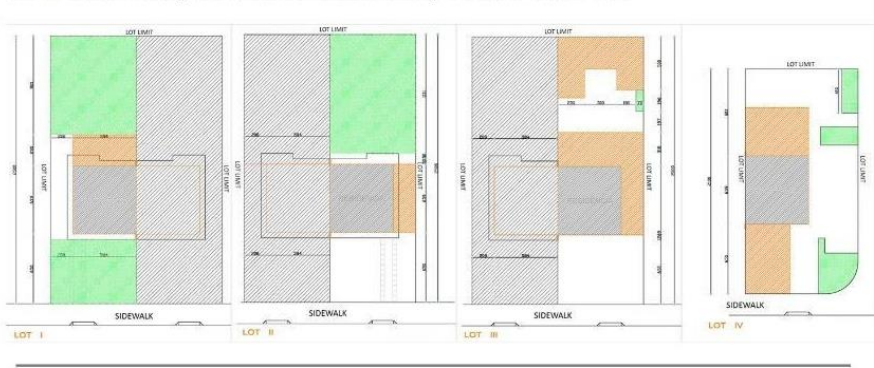

WASTE ACCUMULATION

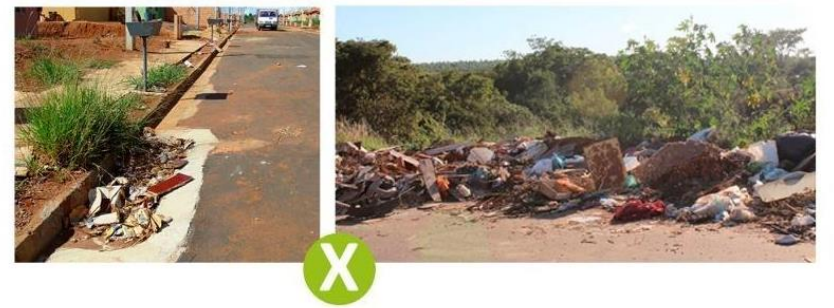

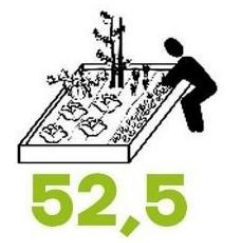

PRODUCE SOME KIND OF FOOD IN THEIR HOMES

FOOD PRODUCTION/ RECYCLING

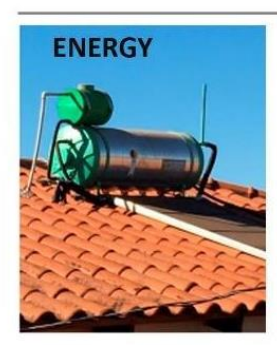

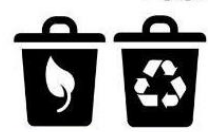

$57,5 \%$

SEPARATES RECYCLABLE WASTE
SEPARATES OIL RESIDUE FROM THE OTHERS

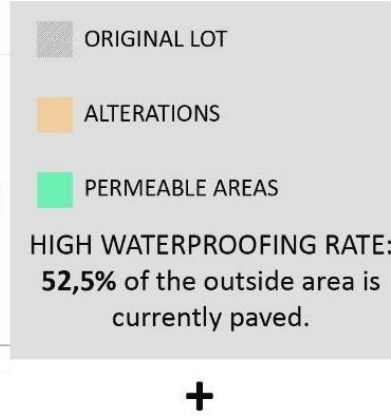

LACK OF GREEN AREAS

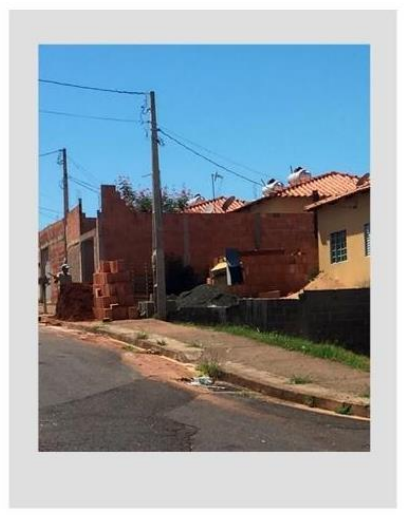

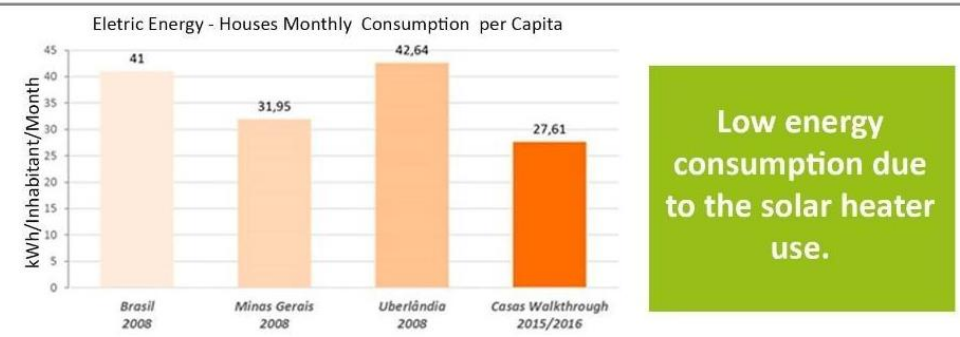

Renovations carried out without adequate technical guidance in $93 \%$ of the houses, added to a waterproofing rate of $52.5 \%$ contribute to the environmental vulnerability of these houses, which are more exposed to floods due to the low possibility of rainwater infiltration. In addition, the presence of garbage/construction rubble in public and private areas contributes not only to the clogging of the rain drainage system, but also to the attraction of unwanted animals and significant aesthetic damage to the allotment, as described by the data in Table 4 and illustrated in Figure 11.

Still, the high percentage of inhabitants demonstrating a variety of adaptive capacities as shown in Table 4 shows a high level of robustness, adaptability and subsequent resilience. The low consumption of water and 
energy needs further investigation in order to find ways to maintain this level, if and when the inhabitants become wealthier.

\section{Housing resilience}

The main vulnerabilities and adaptation capacities regarding the housing resilience are shown in Table 5. Figure 12 highlights the fact that more than half of the interviewed residents are dissatisfied with the size of the houses, the quality of the construction materials used and the acoustic privacy, pointing out several confrontations related to the housing unit that make them vulnerable to changes/impacts. The figure also highlights the lack of sufficient space for circulation within minimally furnished rooms, favouring the occurrence of domestic accidents as well as the low functionality of these environments.

\section{Table 5 - Main results of physical-architectonic order}

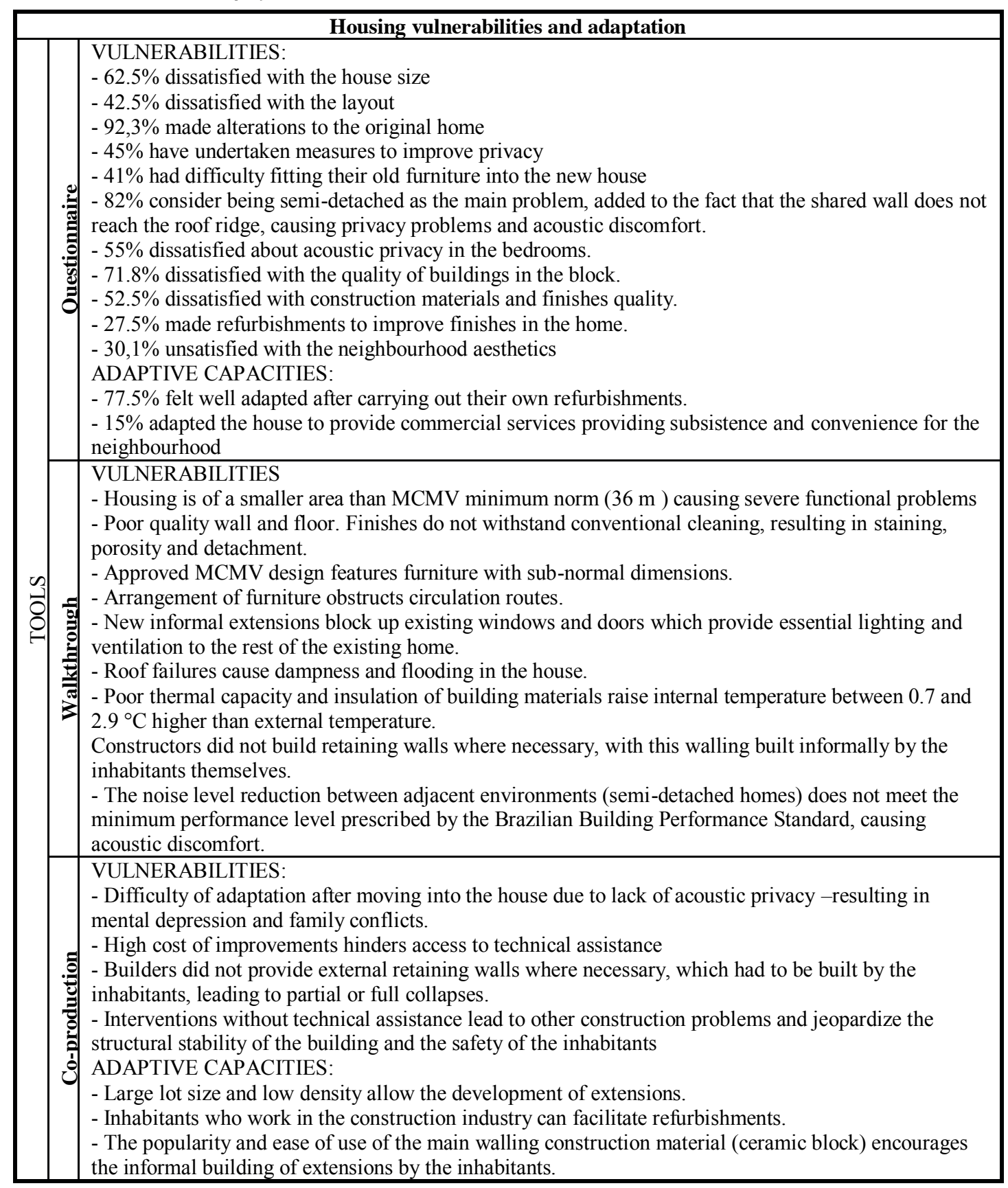

164 Garrefa, F.; Villa, S. B.; , K. C. R. de; Stevenson, F.; Vasconcellos, P. B. 
Figure 12 - Housing resilience
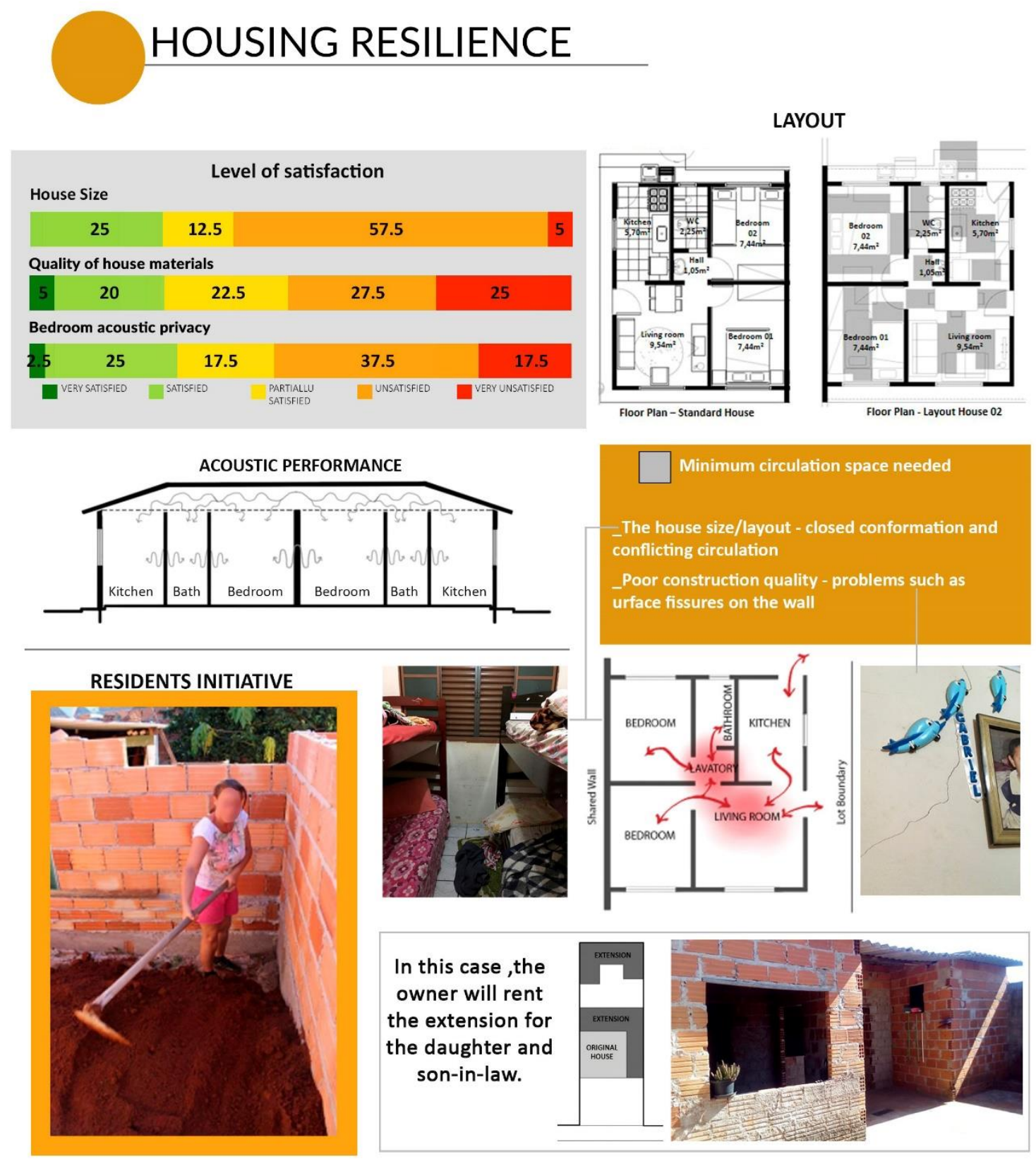

As the housing layout is so limited in size, there is little choice about how to set out furniture, which considerably reduces the redundancy factor needed for resilience through adaptability in the design of the homes. Many inhabitants are, however, able to increase this redundancy in their own homes due to easy access to redundant or cheap materials and the simple construction system of the housing units (load-bearing masonry), and because the lot dimensions allow extensions, which provide good adaptive capacities in the face of a volatile economic scenario. However, these vulnerable refurbishments, often carried out without technical guidance, are not robust and frequently cause new problems such as ingress of rain, threatening the building stability as a whole.

\section{Neighbourhood resilience}

Arguably resilience at the neighbourhood scale is as essential as that of the individual home (STEVENSON; PETRESCU, 2016), with robustness and redundancy related to the vulnerabilities and adaptive capacities available. 
From Table 6 and Figure 13, it is possible to observe that $78.4 \%$ of the interviewed residents are dissatisfied with the health institutions present in the neighbourhood while $48.6 \%$ are dissatisfied with the educational institutions. At the same time, $65 \%$ are very dissatisfied with the public transport system and $71.7 \%$ are dissatisfied with the sidewalk conditions. In other words, issues related to urban infrastructure compromise the circulation of people and access to other locations in the city, depriving these people of enjoying better equipment and opportunities, highlighting the lack of robustness and redundancy in the case studied.

Despite this, it is observed that the dimensions of the lots favour the adaptation of the houses to commercial and service activities, which, although informal and often not regularized, provide restricted opportunities for access and ascension in the complex.

\section{Social resilience}

Finally, Table 7 and Figure 14 present the main social vulnerabilities and adaptive capacities.

It is observed that questions related to the constructive characteristics of the house, which compromise its acoustic performance, often culminate in problems of coexistence between neighbours, in which $70 \%$ of the interviewees feel insecure in the neighbourhood. In addition, the low per capita income added to the characteristics of the delivered project lead to reforms without planning and that extend over time, according to the residents' financial availability.

The lack of money, the waste and the loss of construction materials, the inconvenience resulting from reforms without an end date are not obstacles for interventions to be conducted. On one hand, this behaviour demonstrates the residents' ability to adapt their homes to their needs, despite the difficulties involved. When asked about their satisfaction with housing, $67.5 \%$ generally were satisfied with their home and $77.5 \%$ have adapted well to it. It is noticed, however, that it is often the lack of option that puts these people in a position of conformism and acceptance, demonstrating their vulnerability.

Table 6 - Main results of physical-urbanistic order

\begin{tabular}{|c|c|c|}
\hline \multicolumn{3}{|r|}{ Neighbourhood vulnerabilities and adaptation } \\
\hline & 尊. & $\begin{array}{l}\text { VULNERABILITIES: } \\
-78.4 \% \text { dissatisfied with health facilities } \\
-48.6 \% \text { dissatisfied with existing educational facilities } \\
\text { - } 65 \% \text { very dissatisfied with public transportation } \\
-71.7 \% \text { dissatisfied with the condition of the sidewalk } \\
-71 \% \text { consider that accessibility (universal design) for disabled people is inefficient }\end{array}$ \\
\hline & 青 & $\begin{array}{l}\text { VULNERABILITIES } \\
\text { - Basic Health and Educational facilities do not meet the minimum requirements for the } \\
\text { population size } \\
\text { - The housing development blocks are not appropriate, as they are too large for easy } \\
\text { circulation via walking. } \\
\text { - Accumulation of construction waste obstructs pedestrians on } 54 \% \text { of the sidewalks } \\
\text { - Routes and frequency of public transport is insufficient } \\
\text { ADAPTIVE CAPACITIES: } \\
\text { - The low density (gross density } 100 \text { inhab/ha and net density } 296 \mathrm{hab} / \mathrm{ha} \text { ) favours the } \\
\text { adaptability and flexibility of the residences }\end{array}$ \\
\hline & 兽. & $\begin{array}{l}\text { VULNERABILITIES: } \\
\text { - Very steep and long streets, which hinder accessibility and inclusivity. } \\
\text { - Streets with insufficient traffic signalling. } \\
\text { - Residents consider that the community centre (CEU) is not as useful as it should be, with } \\
\text { faults in its operation, infrastructure and activities offered. } \\
\text { ADAPTIVE CAPACITIES: } \\
\text { - Houses resiliently adapted to provide commerce which represents a convenience to the } \\
\text { neighbourhood }\end{array}$ \\
\hline
\end{tabular}

166 Garrefa, F.; Villa, S. B.;, K. C. R. de; Stevenson, F.; Vasconcellos, P. B. 
Figure 13 - Neighbourhood resilience

\section{PHYSICAL-URBANISTIC ORDER \\ FACILITIES/INFRASTRUCTURE}

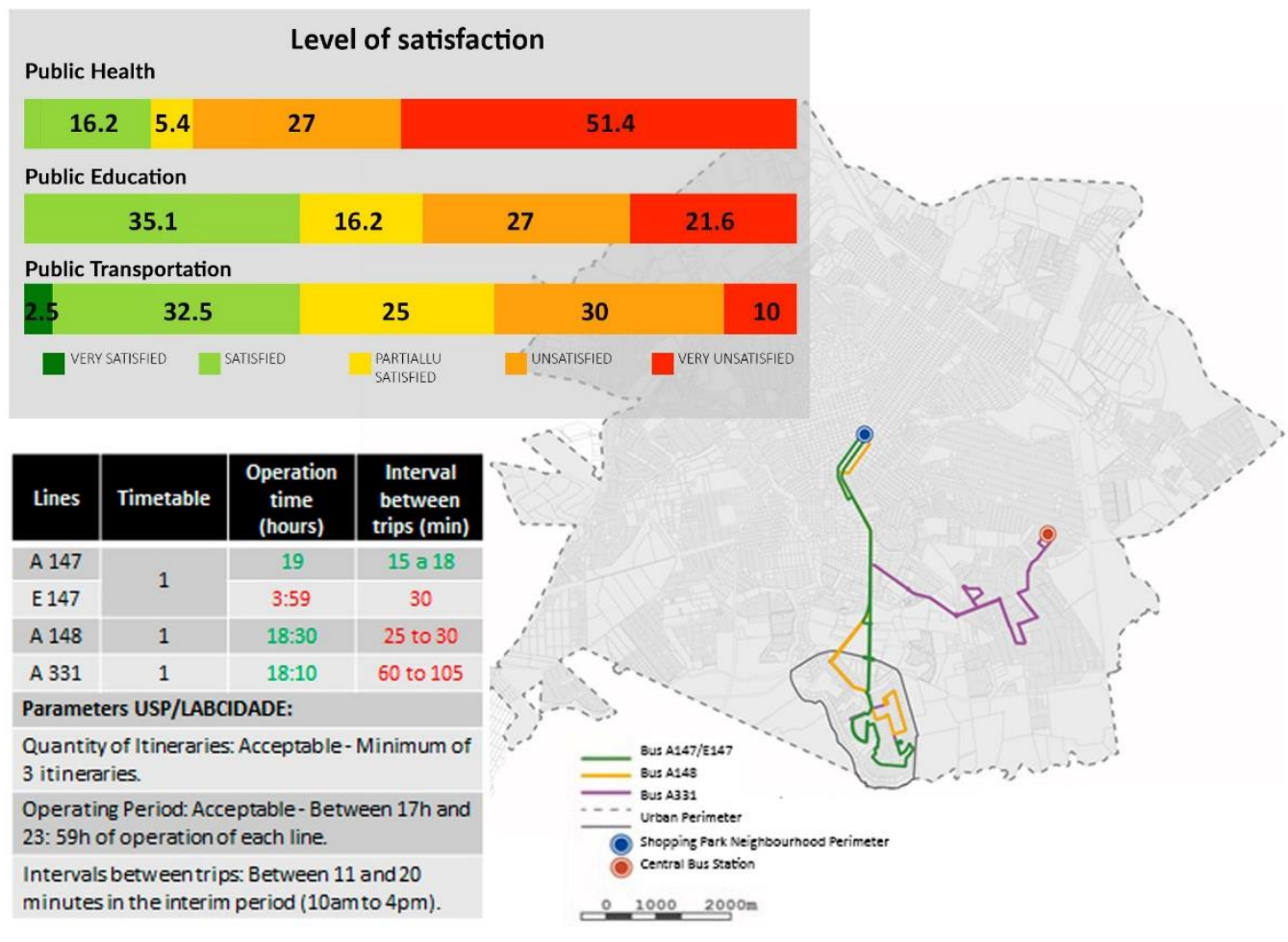

LACK OF ACCESSIBILITY

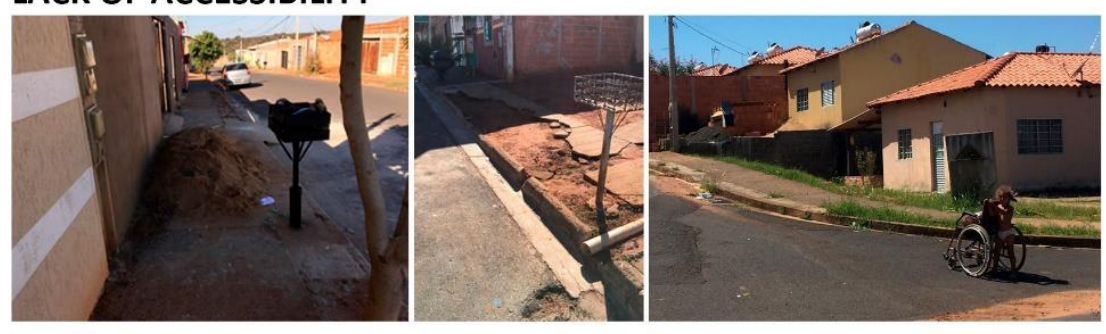

\section{ADAPTATION FOR COMMERCE}
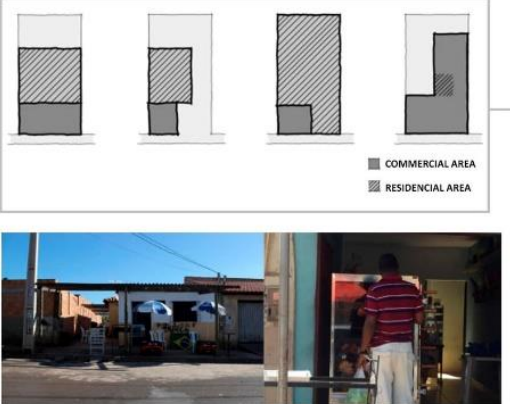

Main forms of adaption currently used.

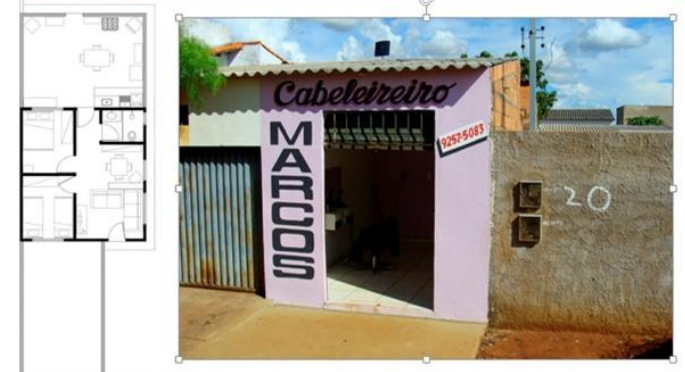


Table 7 - Socio-economic order

\begin{tabular}{|c|c|c|}
\hline & & Social vulnerabilities and adaptation \\
\hline s & & $\begin{array}{l}\text { VULNERABILITIES: } \\
\text { - } 72 \% \text { of respondents reported having a family income of about R } \$ 1,000-2,000 \text { (1 to } 2 \\
\text { minimum wages) } \\
\text { - } 53.8 \% \text { of the households have only one-person working } \\
\text { - } 67.5 \% \text { of these families are single-parent or nuclear } \\
\text { - Average of } 3 \text { to } 4 \text { members being supported by only one person } \\
\text { - } 50 \% \text { dissatisfied about privacy in relation to neighbours } \\
\text { - } 70 \% \text { feel insecure in their neighbourhoods } \\
\text { - } 55 \% \text { feel vulnerable to robbery and the entry of strangers. } \\
\text { ADAPTIVE CAPACITIES: } \\
\text { - } 1.4 \% \text { use the house as a place of leisure and "refuge". } \\
-30 \% \text { use their home to acquire extra income, which reinforces their value. } \\
\text { - } 67.5 \% \text { generally satisfied with their home and } 77.5 \% \text { have adapted well to it. }\end{array}$ \\
\hline & & $\begin{array}{l}\text { VULNERABILITIES } \\
\text { - Project designed for a certain family profile does not address the needs of contemporary } \\
\text { inhabitants } \\
\text { - Monthly family income is below the minimum standard of R } \$ 2765.44 \text {, according to } \\
\text { DIEESE* } \\
\text { * Department of Statistics and Social-economic Studies }\end{array}$ \\
\hline & & $\begin{array}{l}\text { VULNERABILITIES: } \\
\text { - High cost involved with reforms overburden the family income } \\
\text { - Difficulty of adaptation in post-change, mainly due to the lack of acoustic privacy } \\
\text { - Inhabitants make less use of the community centre (CEU) due to insecurity, mainly because } \\
\text { of drug trafficking on site } \\
\text { - Lack of street lighting - creates insecurity }\end{array}$ \\
\hline
\end{tabular}

\section{Discussion}

At first glance, results pointed out some typical findings in previous research dealing with MCMV programme. Peripheralization of the complexes, high dependency of individual motorized transportation, lack of quality in the public transportation, educational and health facilities, poor construction quality and weak design are some of the numerous issues observed in these neighbourhoods (SHIMBO; CERON, 2014; RUFINO, 2015; VILLA; SARAMAGO; GARCIA, 2015; MARICATO, 2000; CABRITA, 1995). On the other hand, this work seeks to have a different approach using the concept of resilience which considers these issues as impacts capable of leading to vulnerabilities and adaptive capacities (BORTOLI, 2018; GARCIA; VALE, 2017; RODIN, 2015; PICKETT et al., 2014; HASSLER; KOHLER, 2014; LEMOS, 2014; DAVOUDI; CRAWFORD; MEHMOOD, 2009; MAGUIRE; CARTWRIGHT, 2008). In the selected area, one can note that vulnerabilities are still the main results from the impacts in the community. However, important findings are observed in regards to adaptive capacities.

Around $30 \%$ of respondents use their home to acquire extra income, which increases feelings of security by providing life in the street with the presence of local businesses, as well as helping to make the monthly household income more resilient. However, there is a lack of any policy to legalise these local businesses which also leaves them vulnerable and potentially reduces the social resilience of the neighbourhood over the long term.

Positive resilience factors include the community's ability to produce food and recycle waste which is even a source of income for some - as identified in the co-production meetings. However, this resilient behaviour is limited by local policies, which fail to provide collection or recycling points nearby that can expand these activities in the neighbourhood to promote social capital.

168 Garrefa, F.; Villa, S. B.; , K. C. R. de; Stevenson, F.; Vasconcellos, P. B. 
Figure 14 - Social resilience
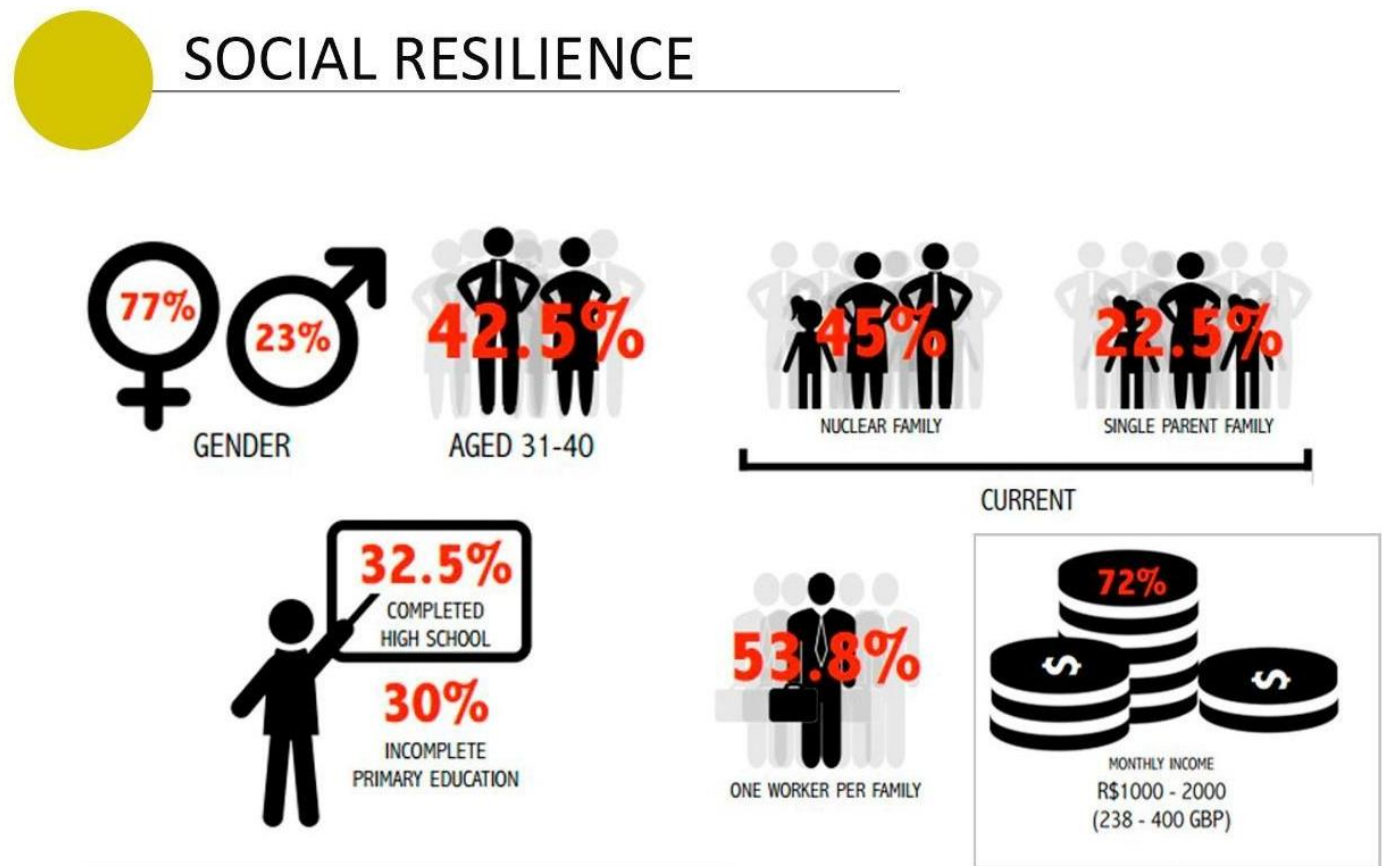

\section{VIOLENCE/SAFETY}
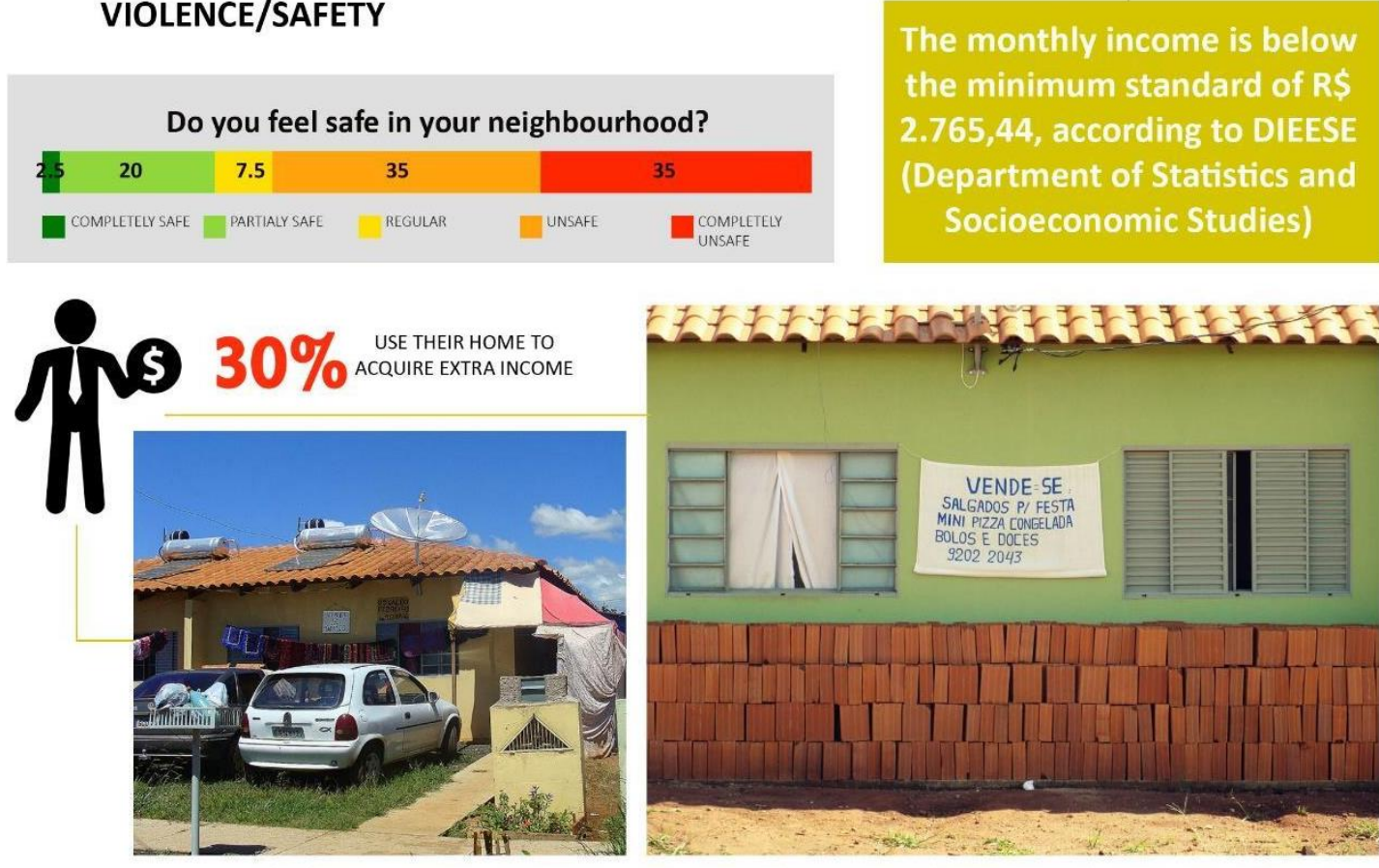

"Selling carpets"

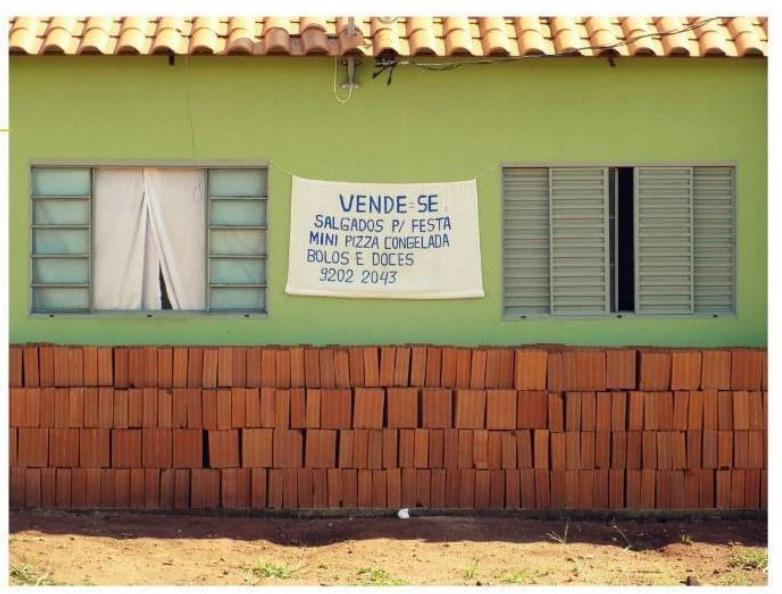

"Selling pastries, pizza, cakes and sweets for parties"

The main physical resilience factor lies in the flexibility and adaptability of the plot sizes in relation to the houses. This enabled inhabitants to significantly improve the commerce in the area through adapting homes to provide individual extensions for new social and commercial services in the neighbourhood. There is an argument that the densification of the MCMV housing typology through incremental extensions to individual homes and commercial conversions could help to make such developments more resilient overall through increased interactions. Nevertheless, such development would not necessarily impact negatively on the transport infrastructure. Indeed, by making these developments more resilient through the provision of more local services, the pressure on transport infrastructure and public transport into the city could be reduced through a greater autonomy. 
The informal adaptation of homes to provide commercial activities has helped inhabitants to generate a more mutually supportive coexistence at the local level. In addition, the co-production meetings made it possible to share local knowledge and solutions among inhabitants, and between them and the academics, developing motivations and behaviours based on the concept of resilience.

Such poor conditions motivate inhabitants to carry out informal adaptations to meet their needs. Thus, positive resilient behaviour is evidenced by the inhabitants' intention to change their surroundings. These transformations are also directly related to the threats posed to the community such as insecurity construction defects and inadequate public infrastructure, which have to be addressed despite scarce personal and community resources. Lack of technical guidance for these adaptations generates several other problems for the family and the neighbourhood, as discussed below.

This inability to adapt houses to increase their resilience is also reflected in the lack of resources to hire suitable professionals to make changes in homes. The inhabitants' sense of insecurity - as expressed during co-productions - also weakens the resilience, as this limits relationships within neighbours and defines rigid, inflexible physical aspects of houses and lots, such as the creation of high walls. Also, the existing infrastructure creates further insecurity, due to inadequate lighting and illicit activities taking place in public leisure facilities. In this sense, there is a lack of community self-surveillance that can increase inhabitants safety and improve neighbourhood relations as a form of social resilience.

However, observing these adaptive capacities as a sign of resilience, as written before, vulnerabilities still constitute a major challenge to residents.

The lack of resilience of the built environment, with the existing limitations, generates environmental problems at several levels. In terms of environmental resilience, the MCMV project does not incorporate resilience strategies, forcing residents to increase the level of adaptation as the project degenerates. However, these informal adaptations cause problems such as construction waste dumped in public areas, poor storage and disposal facilities, and increased impermeability of the ground within a housing lot, which impairs soil water absorption, affects thermal comfort and increase local flood problems.

At the neighbourhood resilience level, there is significant dissatisfaction with ineffective public services and equipment. The physical structure of the neighbourhood also creates vulnerabilities with uneven sidewalks due to the poor quality of existing material and rubbish placed on them, as well as the long blocks that increase the distances to bus stops and other equipment. All of these factors diminish the interaction between individuals and the community, which affects social resilience at the neighbourhood level, as the mutual sharing of resources and support through healthy bonds generated between residents through their informal activities mitigates impacts through increased community strength.

By contrast, the greatest neighbourhood vulnerabilities lie in the poorly planned public and commercial facilities/areas, as well as the poor layout and construction of the local area which has led to significant flooding and landslides. Additional robustness for the retaining walls around the houses is needed in order to develop improved resilience towards future climate events, which are predicted to be more extreme, such as intense rain bursts.

At the individual house level, the poor quality of the construction as well as the small size of the houses, has resulted in a reduced level of redundancy with little option for inhabitants to be able to adapt their home to changes in the size and requirements of the family over time.

Adaptations in this low-cost housing development are frequently made to increase the overall redundancy of the homes and the overall neighbourhood through increased commercial service provision. However, these informal interventions leave the homes vulnerable due to poor construction techniques with inadequate construction knowledge. The resulting vulnerabilities, such as poor acoustics, critical infrastructure, overheating, and flooding due to ground sealing of the surrounding garden areas need urgent attention, given the rapid rate of climate change, which is predicted to exacerbate these issues in the near and long term future.

The research's definition of resilience is anchored in the ability to resist, adapt and transform in order to address, in a positive manner, changes or impacts imposed over time. The results clearly demonstrate these residents' inherent ability, as they are adapting and transforming themselves and their homes in order to cope with a difficult reality of lack of infrastructure, deprived socioeconomic conditions, poor housing quality and climate change - impacts which are continuously showing its effects over time. Nevertheless, the limits imposed by scarce resources and local policies, alongside the lack of technical assistance, hinders the resilience growth in this built environment, as initially defined by the presented research project.

170 Garrefa, F.; Villa, S. B.; , K. C. R. de; Stevenson, F.; Vasconcellos, P. B. 
Therefore, greater resilience needs to be incorporated into the design of these units and existing policies, so that they can leverage the inherent resilient capacities of these communities. Nevertheless, the inhabitants themselves already have a high degree of social resilience and continuously look for creative ways to adapt to the new realities presented, both in relation to their homes and their neighbourhood. However, as the informally planned extensions and alterations to the houses were not foreseen in the original project, the inhabitants usually create new cross-circulation routes within the home which harm the privacy of the more intimate zones (such as bedrooms and baths) as well as reducing the comfort conditions regarding natural ventilation and illumination. Despite these difficulties, the level of use of these spaces by the residents is high, due to the family and contextual demands.

\section{Conclusion}

This paper has innovatively demonstrated a modified POE and co-production process for assessing the vulnerabilities and resilience of a housing development. The findings raise some overall issues that need to be explored further. The study shows that the housing sampled as representative of an MCMV housing project in Brazil presents innumerable construction, functional and environmental problems. High levels of inhabitant dissatisfaction were observed in relation to the way these houses are inserted in the city and their marginal relationship with the urban space, as well as the limiting repetitive nature of the typology, due to the inability to attend to different family profiles and changing needs. Therefore, remodelling and adaptations in these low-cost homes occur very frequently and seen as essential.

In this case study, the number of adaptive interventions carried out is very large. These interventions are made in a natural and intuitive way by their residents, who make them according to their economic possibilities and low level of information, resulting in the unnecessary waste of raw materials, compromised structures of the houses, and poor environmental comfort, among other negative consequences.

These are generic problems that have been shown to occur in different Brazilian social and climatic contexts, as shown by housing studies developed by TCU (TRIBUNAL..., 2018), Villa et al. (2017), Vasquez (2017), Brasileiro, Morgado and Luz (2017), Amore, Shimbo and Rufino (2015) and IPEA (INSTITUTO..., 2014).

Nevertheless, this study has uniquely shown that the responding MCMV residents are very resilient in terms of looking for creative ways to adapt to the new reality provided for them, both in relation to their dwelling and regarding the neighbourhood in which they find themselves. When evaluating the modified houses, problems at various levels were identified. As the adaptations were not foreseen in the original project, the inhabitants ended up with reduced comfort conditions regarding natural ventilation and illumination, and increased social and physical vulnerability within their homes and neighbourhood.

Although the case study demonstrated energy and water consumption well below the city of Uberlândia average, as well as a great level of recycling from household waste, these facts do not relate to any public policy concerning sustainability and resilience except the requirement for solar water heaters, included in the original design. These achievements are instead the result of the particular socioeconomic condition of the inhabitants. Thus, they are driven by necessity to save resources in various ways, representing a much more personal motivation towards resource economy than a collective conscience of diminishing the environmental impact of their home and neighbourhood. How can this paradox be accounted for in future housing design?

The findings indicate that a broad knowledge of local housing issues - involving public, collective and private consultation - is essential, when developing concepts, guidelines and parameters for designing resilient housing projects. POEs combined with co-production methods can help to guarantee more resilient housing projects, which are economically viable and generate higher levels of satisfaction. Co-production could, in the long term, contribute to the increase of the resilience of neighbourhoods, as the participation of the inhabitants in this holistic process promotes not only design that is more appropriate to their needs, with increased resilience and adaptability, but also the establishment of qualitative guidelines for future projects/constructions. Following this innovative hybrid research approach, this study will continue with further co-production actions in two subsequent stages ( 2 and 3) between 2017 and 2019.

Finally, it is clear from both the co-production sessions and the wider studies undertaken in Shopping Park, that inhabitants have been saturated with previous unfulfilled initiatives and promises, and they thus remain doubtful. Researchers are potentially in a strong position to work with other stakeholders, such as NGOs and industry, working in the local area, in order to identify possible resources (e.g. building materials, re-used materials) and physical interventions to improve the MCMV housing developments in the first instance. 
However, without direct engagement with the inhabitants these initiatives will inevitably fail. Small physical interventions, correctly designed, and working directly with the inhabitants themselves, are an essential way forward as identified in this study. A significant social resource for developing resilience exists within these housing communities in terms of capable communicators, organisers, homeworkers, builders and electricians who should be encouraged to co-produce any future research and interventions. Thus, a future pilot intervention developed through co-production as a next stage in this study will be carefully monitored in order to evaluate and modify, if necessary, the proposition before planning a wider implementation.

The aim of this research is to make a real and practical difference to Brazilian inhabitants in the MCMV programme by identifying key resilience issues in order to provide detailed guidelines for more adaptable and resilient housing projects in a local context, and the possibility of developing constructive interventions in the future.

This research has highlighted the need to retrofit the stock of MCMV social housing in Brazil, always considering the values and resources invested in them, based on the high levels of dissatisfaction experienced by a large amount of the population. The promotion of urban resilience requires that any initiative to encourage the retrofitting of these housing developments always consider first the current impact they represent on the natural, social and economic systems of Brazilian cities.

To achieve social and built environment resilience, it is thus essential to co-produce community resilience through the provision of technical advisory services resulting from the research carried out with the inhabitants - not for them. Unlike technical assistance without co-production, which leads inhabitants to adapt (increasingly) to a pre-identified pattern of needs and satisfaction, professional advice generated through co-production can help inhabitants to articulate their own demands and, with increasing autonomy and empowerment, decide how to meet them. This fulfills one of the pre-requisites for resilience which is the social engagement for collective problem-solving.

\section{References}

AMORE, C. S.; SHIMBO, L. Z.; RUFINO, M. B. C. (org.). Minha Casa... e a Cidade? Rio de Janeiro: Letra Capital, 2015.

ANGÉLIL, M.; HEHL, R. Minha Casa-Nossa Cidade: innovating mass housing in: Brazil. Berlin: Ruby Press, 2014.

ARUP; THE ROCKEFELLER FOUNDATION. City Resilience Index. 2015. Available at:

https://www.arup.com/perspectives/publications/research/section/city-resilience-index. Access in: 03 Mar. 2018.

BIDERMAN, C. et al. Morar longe: o Programa Minha Casa Minha Vida e a expansão das Regiões Metropolitanas. São Paulo: CEPESP/FGV/Instituto Escolhas, 2019. Available at:

http://www.escolhas.org/wp-content/uploads/2019/04/QCML_RELATORIOFINAL_Site.pdf. Access in: 27 October. 2019.

BORTOLI, K. C. R. Avaliando a resiliência no ambiente construído: adequação climática e ambiental em habitações de interesse social no Residencial Sucesso Brasil (Uberlândia/MG) - Uberlândia. Uberlândia, 2018. 281 f. Dissertação (Mestrado em Arquitetura e Urbanismo) - Faculdade de Arquitetura e Urbanismo e Design, Universidade Federal de Uberlândia, Uberlândia, 2018.

BOYLE, D.; HARRIS, M. The Challenge of Co-production. 2009. Available at: https://media.nesta.org.uk/documents/the_challenge_of_co-production.pdf. Access in: 30 Aug. 2018.

BRASILEIRO, A.; MORGADO, C.; LUZ, C. Conjunto do PMCMV no RJ: razões da (in) eficiência energética no decorrer de sua vida útil. In: ENCONTRO NACIONAL DE CONFORTO NO AMBIENTE CONSTRUÍDO, 15.; ENCONTRO LATINO-AMERICANO DE CONFORTO NO AMBIENTE CONSTRUÍDO: HABITAT HUMANO: EM BUSCA DE CONFORTO AMBIENTAL, EFICIÊNCIA ENERGÉTICA E SUSTENTABILIDADE NO SÉCULO XXI, 10., Camboriú, 2017. Anais [...] Camboriú: ANTAC, 2017.

BROOKS, N. Vulnerability, risk and adaptation: a conceptual framework. Tyndall Centre Working Paper No. 38. University of East Anglia, 2003.

CABRITA, A. M. R. O homem e a casa: definição individual e social da qualidade da habitação. Lisboa: Laboratório Nacional de Engenharia Civil, 1995.

172 Garrefa, F.; Villa, S. B.;, K. C. R. de; Stevenson, F.; Vasconcellos, P. B. 
DAVOUDI, S.; CRAWFORD, J.; MEHMOOD, A. Planning for climate change: strategies for mitigation and adaptation for spatial planners. London: Earthscan, 2009.

ELIAS-TROSTMANN, K. et al. Mais forte do que a tempestade: aplicando a avaliação de resiliência comunitária urbana aos eventos climáticos extremos. Documento de Trabalho. Washington: World Resources Institute. Available at: https://www.wri.org/publication/stronger-than-the-storm. Access in: 05 Feb. 2020.

FLYVBJERG, B. Five misunderstandings about case-study research. Qualitative Inquiry, v. 12, n. 2, p. 219-245, apr. 2006.

GARCIA, J. E.; VALE, B. Unravelling sustainability and resilience in the built environment. London: Routledge, 2017.

HASSLER, U.; KOHLER, N. Resilience in the built environment. Building Research \& Information, v. 42, n. 2, p. 119-129, 2014.

HIRATA, F. "Minha Casa, Minha Vida": política habitacional e de geração de emprego ou aprofundamento da segregação urbana? Revista Aurora, v. 3, n. 4, jul. 2009.

HOLLING, C. Resilience and Stability of Ecological Systems. Annual Review of Ecology and Systematics, v. 4, n. 1, p. 1-23, 1973.

INSTITUTO DE PESQUISA ECONÔMICA APLICADA. Pesquisa de satisfação dos beneficiários do Programa Minha Casa Minha Vida. Brasília, 2014. Relatório Técnico.

LEAMAN, A.; STEVENSON, F.; BORDASS, B. Building Evaluation: practice and principles. Building Research and Information, v. 38, n. 5, p. 564-577, 2010.

LEMOS, M. F. Sustentabilidade e resiliência. In: ENCONTRO DA ASSOCIAÇÃO NACIONAL DE PESQUISA E PÓS-GRADUAÇÃO EM ARQUITETURA E URBANISMO, 3., São Paulo, 2014. Anais [...] São Paulo: ANPARQ, 2014.

MAGUIRE, B.; CARTWRIGHT, S. Assessing a community's capacity to manage CHANGE: a resilience approach to social assessment. Canberra: Comonwealth of Australia, 2008.

MALLORY-HILL, S.; PREISER, W.; WATSON, C. Enhancing building performance. London: WileyBlackwell Press, 2012.

MARICATO, E. Habitação social em áreas centrais. Revista de Arquitetura e Urbanismo Óculum Ensaios, Campinas, v. 1, n. 1, p. 13-24, 2000.

MEEROW, S.; NEWELL, J.; STULTS, M. Defining urban resilience: a review. Amsterdam: Landscape and Urban Planning, 2015.

PETCOU, C.; PETRESCU, D. R-URBAN or how to produce a resilient city. EPHEMERA Theory \& Politics Organization, v. 15, n. 1, p. 249-262, 2015.

PETRUCCI, E. Características do clima de Uberlândia-MG: análise da temperatura, precipitação e umidade relativa. Uberlândia, 2018. 245 f. Dissertação (Mestrado em Geografia e Gestão do Território) Instituto de Geografia/Universidade Federal de Uberlândia, Uberlândia, 2018.

PICKETT, S. T. A. et al. Ecological resilience and resilient cities. Building Research \& Information, v. 42, n. 2, p. 143-157, 2014.

RODIN, J. The resilience dividend. Great Britain: Profile Books, 2015.

RUFINO, M. B. C. Um olhar sobre a produção do PMCMV a partir de eixos analíticos. In: AMORE, C. S.; SHIMBO, L. Z.; RUFINO, M. B. (org.). Avaliação do Programa Minha Casa Minha Vida em seis estados brasileiros. Rio de Janeiro: Letra Capital, 2015.

SHIMBO, L. Z.; CERON, L. C. Produção do PMCMV na Região Central do Estado de São Paulo: um híbrido entre ocupação nas periferias e em áreas consolidadas. In: ENCONTRO DA ASSOCIAÇÃO NACIONAL DE PESQUISA E PÓS-GRADUAÇÃO EM ARQUITETURA E URBANISMO, 3., São Paulo, 2014. Anais [...] São Paulo, 2014.

SMIT, B.; WANDEL, J. Adaptation, adaptive capacity and vulnerability. Global Environmental Change, v. 16 , p. $282-92,2006$. 
STEVENSON, F.; BARBORSKA-NAROZNY, M.; CHATTERTON, P. Resilience, redundancy and lowcarbon living: co-producing individual and community learning. Building Research and Information, v. 44, n. 7, p. 789-803, 2016.

STEVENSON, F.; PETRESCU, D. Co-producing neighbourhood resilience. Building Research \& Information, v. 44, n. 7, p. 695-702, 2016.

TRIBUNAL DE CONTAS DA UNIÃO. As novas possibilidades para o programa Minha Casa, Minha Vida. 2018. Available at: https://www12.senado.leg.br/noticias/especiais/especial-cidadania/as-novaspossibilidades-para-o-programa-minha-casa-minha-vida. Access in: 15 Sep. 2018.

UNITED NATIONS HUMAN SETTLEMENTS PROGRAMME. UN-Habitat Annual Report 2011. Nairobi: UNON, UM-HABITAT, 2011.

UNITED NATIONS. New Urban Agenda (NUA). Republico of Ecuador: Habitat III Secretariat, 2017. Available at: http://habitat3.org/wp-content/uploads/NUA-English.pdf. Access in: 04 Sep. 2018.

VASQUEZ, E. M. A. Análise do conforto ambiental em projetos de habitações de interesse social segundo a NBR 15575:2013. Rio de Janeiro, 2017. Dissertação (Mestrado em Engenharia Ambiental) Programa de Pós-Graduação em Engenharia Urbana Ambiental, Pontifícia Universidade Católica do Rio de Janeiro, Rio de Janeiro, 2017.

VILLA, S. B. et al. Método de análise da resiliência e adaptabilidade em conjuntos habitacionais sociais através da avaliação pós-ocupação e coprodução. Uberlândia: Universidade Federal de Uberlândia, Universidade de Sheffield, 2017. Relatório final de pesquisa.

VILLA, S. B.; OLIVEIRA, J. C. C. B.; SARAMAGO, R. Respostas ao problema habitacional brasileiro: o caso do projeto MORA. In: CONGRESSO INTERNACIONAL DA HABITAÇÃO NO ESPAÇO LUSÓFONO, 2.; CONGRESSO INTERNACIONAL DA HABITAÇÃO NO ESPAÇO LUSÓFONO: HABITAÇÃO, CIDADE, TERRITÓRIO E DESENVOLVIMENTO, 2. Lisboa, 2013. Anais [...] Lisboa: Laboratório Nacional de Engenharia Civil , 2013.

VILlA, S. B.; SARAMAGO, R. C. P.; GARCIA, L. C. Avaliação Pós-Ocupação no Programa Minha Casa Minha Vida: uma experiência metodológica. Uberlândia: Universidade Federal de Uberlândia, 2015.

\section{Acknowledgements}

This work was supported by the Santander Research Mobility Awards SSoA; FAPEMIG, CNPq, Brazil; PROGRAD/UFU; CAPES; and the University of Sheffield/TUoS, UK. 
Fernando Garrefa

Facauldade de Arquitetura e Urbanismo e Design | Universidade Federal de Uberlândia | Av. João Naves de Ávila, 2121 | CEP $38408-100$ | Uberlândia - MG - Brasil | Tel.: (34) 3239-4373 | E-mail: fgarrefa@ufu.br

\section{Simone Barbosa Villa}

Facauldade de Arquitetura e Urbanismo e Design | Universidade Federal de Uberlândia | E-mail: simonevilla@yahoo.com

\section{Karen Carrer Ruman de Bortoli}

Instituto de Geografia | Universidade Federal de Uberlândia | E-mail: karencrbortoli@gmail.com

\section{Fionn Stevenson}

School of Architecture | University of Sheffield | Western Bank Sheffield S10 2TN | Sheffield - United Kingdom | Tel.: +(44) 114 222-0399 | E-mail: f.stevenson@sheffield.ac.uk

\section{Paula Barcelos Basconcellos}

Facauldade de Arquitetura e Urbanismo e Design | Universidade Federal de Uberlândia | E-mail: paulab_vas@yahoo.com.br

\section{Ambiente Construído}

Revista da Associação Nacional de Tecnologia do Ambiente Construído

Av. Osvaldo Aranha, $99-3^{\circ}$ andar, Centro

Porto Alegre - RS - Brasil

$$
\text { CEP } 90035-190
$$

Telefone: +55 (51) 3308-4084

Fax: +55 (51) 3308-4054

www.seer.ufrgs.br/ambienteconstruido

E-mail: ambienteconstruido@ufrgs.br 